\title{
Küreselleşmenin Kent Yönetimlerinde Meydana Getirdiği Değişim: Yabancılar Meclisi, Alanya Örneği ${ }^{1}$
}

\author{
Change Caused By Globalization in The City Management: Foreigners Council, The Case Study of \\ Alanya
}

\section{Burak YILDIRIM}

Yüksek Lisans Öğrencisi, Akdeniz Üniversitesi, SBE, burak20130403083@gmail.com

https://orcid.org/0000-0002-9469-6453
Makale Başvuru Tarihi: 23.11.2019

Makale Kabul Tarihi: 29.12.2019

Makale Türü: Araştırma Makalesi

\author{
Bekir AYHAN \\ Yüksek Lisans Öğrencisi, Mehmet Akif Ersoy Üniversitesi, \\ SBE, bekirayhan91@gmail.com \\ https://orcid.org/0000-0001-5409-6165
}

$\begin{aligned} & \text { Anahtar } \\ & \text { Kelimeler: }\end{aligned}$
Küreselleşme,
Kent Yönetimi,
Yerleşik Yabancı,
Yabancılar
Meclisi,
Alanya,

Keywords:

Globalization,

City Management,

Resident Foreigner,

Foreigners Council Alanya,

\section{ÖZET}

1980 sonrası dönemde küreselleşmenin meydana getirdiği değişim süreçlerine, kent yönetimleri de dahil olmuştur. Kent yönetimlerinin süreçlere dahil olması, katı ulusal sintrların ve hiyerarşinin ortadan kalkmasıyla gerçekleşmeye başlamıştır. Merkezi yönetimlerin çeşitli yetki ve otoritelerinin yerel düzeyle paylaşılmasıyla kent yönetimleri yeniden șekillenmiştir. Ayrıca küreselleşmenin dolaylı etkilerinin yansıdığ yönetişim, genel olarak yönetim alanında hakim duruma gelmiştir. Yönetişimin kent yönetimlerinde de etkin hale gelmeye başlamasıyla katılımın ve yerel demokrasinin arttı̆̆ kent yönetimleri, "küresel için yerelde birliktelik" mottosu ile hareket etmeye başlayan yönetim modeli haline gelmiştir. Küreselleșmenin etkisiyle uluslararası göç hareketlerinin hızlanması sonucu kentlerde birçok etnik unsur bir arada yaşamaya başlamıştır. Yerleşik yabancı olarak tanımlanan yabancı ülke vatandaşları, kentlere adapte olabilmek ve kent yönetimlerinde yer alabilmek adına çeşitli yapılanmalar içerisinde yer almaya başlamıştır. Avrupa Birliği'ndeki yabancı vatandașların kentlerdeki yönetim alanına dahil olabilmesi, "Yabancıların Yerel Düzeyde Kamusal Hayata Katılımına Illişkin Sözleşme” çerçevesinde oluşturulan danışma kurulu niteliğindeki meclislerle gerçekleştirilmektedir. Türkiye'nin sözleşmeye taraf olmaması sonucu, Türkiye'de ilk ve tek örneğini oluşturan, yerleşik yabancıların katılımıyla oluşturulmuş, danışma kurulu niteliğindeki Alanya Yabancılar Meclisi; temellerini gönüllülük esasına dayandırmaktadır. Çalışmamızda yerleşik yabancıların yerel düzeyde kamusal yaşama katılımlarının kent yönetimlerindeki etkilerinin ortaya konulması amaçlanmaktadır. Çalışma kapsamında teorik ve genel bilgilendirmeler literatür üzerinden tarama yapılarak, çalışmanın uygulama kısmı ise mülakat yöntemiyle alan çalıșması gerçekleștirilerek oluşturulmuştur.

\section{ABSTRACT}

City managements have also been involved in the process of changing that globalization has brought in the post-1980 period. The involvement of the city management in the process has begun to take place with the rigid national borders and getting out of the way of hierarchy. City managements are reshaped by the sharing of various warrants and authorities of central management at the local level. Moreover, governance, which is reflected by the indirect effects of globalization, has become dominant in the management field in general. As governance began to become effective in city management, the participation of local management and the rise of local democracy became a management model that has begun to move with the motto of "coexistence in the locality for the global". Many ethnic elements have begun to coexist in cities that have been accelerated by international migration movements under the influence of globalization. Citizens of

1 Bu makale, 1-3 Kasım 2018 tarihleri arasında gerçekleştirilen, Alanya Uluslararası Yerel Yönetimler Sempozyumunda sunulan "Küreselleşmenin Kent Yönetiminde Meydana Getirdiği Değişimler: Alanya Yabancılar Meclisi Örneği” konulu bildiri tam metninden zenginleştirilerek elde edilmiştir. 
foreign countries, who are defined as resident foreigners, have begun to take part in various structures in order to be able to adapt to cities and take part in city management. To be able to involve in city management of foreign citizens in the US is carried out by the parliaments of the advisory committee that is formed under the "Convention on Foreigners' Participation in Public Life at the Local Level". The result of not to be a party to the agreement, the first and only example in Turkey; Alanya Foreign Assembly is an advisory board, which is formed with the participation of foreign residents that is based on volunteerism. The purpose of our work is to demonstrate the impacts of local residents' involvement in public life at the local level in city management. Within the scope of the study, the theoretical and general informants were screened through the literature, and the application part of the study was formed by developing the field study with the interview method.

\section{GÍRIŞ}

1980 sonrası dönemde küreselleșmenin dünya üzerinde sosyokültürel, ekonomik, siyasal ve yönetsel alanlarda meydana getirdiği değişim süreçlerine kentler ve dolayısıyla kent yönetimleri de dahil olmaktadır. Kent yönetimlerinin bu sürece dahil olması, ulus devletlerde merkezi yönetimlerin hakimiyetlerinin azalmaya başlaması ve katı ulusal sınırların, hiyerarşinin ortadan kalkması sonucunda gerçekleşmeye başlamıştır. Merkezi yönetimlerin çeşitli yetki ve otoritelerini yerelle paylaşmasıyla kent yönetimleri şekillenirken, kent yönetimlerinde küreselleşmenin de dolaylı yansımalarıyla yönetim alanına hakim hale gelen yönetişim anlayışının etkileri gözlenmektedir. Kent yönetimleri "küresel için yerelde birliktelik" mottosu ile hareket etmeye başlarken, yönetişim anlayışıyla birlikte, katılımın ve yerel demokrasinin arttığı yeni bir yönetim modeline evirilmektedir.

Kent yönetimlerinde meydana gelen değişim, sınırları ulusal ve uluslararası kurum ve kuruluşlar aracıllğıyla gerçekleştirilen yasal düzenlemelerle şekillendirilmektedir. Bu alanda Avrupa Birliği ve onun bünyesinde bulunan birimler tarafından gerçekleştirilen yasal düzenlemeler, önemli bir konumda yer almaktadır. Uluslararası düzenlemeler içerisinde yer alan "Yabancıların Yerel Düzeyde Kamusal Yaşama Katılmasına İlişkin Sözleşme" yabancıların kent yönetimine katılımını ve kente uyumunu sağlayabilmeleri amaciyla oluşturulmuş bir düzenlemedir. Düzenleme çerçevesinde yerleşik konumda bulunan yabancıların kent yönetimlerine katılımının ve kente uyumunun sağlanabilmesi adına çeşitli kurum ve kuruluşların oluşturulması gerektiği belirtilmektedir. Yabancıların Yerel Düzeyde Kamusal Yaşama Katılmasına İlişkin Sözleşme, taraf olan Avrupa Konseyi üyesi devletlerin kendi bünyelerindeki yerleşik yabancıları, kent yönetimine dahil edebilmek adına danışma kurulu niteliğinde meclislerin oluşturulması fikrine yer vermektedir. Sözleşmeye taraf olan ülkelerde genellikle "Yabancılar Meclisi" adı ile meclisler oluşturmaktadır.

Küreselleşmenin dünya üzerinde meydana getirdiği değişim sürecinden Türkiye'de etkilenmektedir. Ancak Avrupa Birliği ve çeşitli uluslararası kuruluşların oluşturdukları düzenlemelerin birçoğuna taraf olmamakla birlikte değişim sürecinde düzenlemelerin takipçisi görünmektedir. Takipçiliğin en büyük örneğini; Yabancıların Yerel Düzeyde Kamusal Yaşama Katılmasına İlişkin Sözleşmeye taraf olmamasına rağmen, ilk ve tek olarak Alanya'da kent yönetimlerine yabancıların katılımını sağlayabilmek adına, danışma kurulu niteliğindeki Yabancılar Meclisi’nin oluşturulması üzerinden göstermektedir.

Bu çalışmada 1980 sonrası süreçte küreselleşmeyle birlikte kent yönetimlerinde meydana gelen değişimler, Alanya Yabancılar Meclisi örneği üzerinden aktarılmaya çalışılmaktadır. Ayrıca çalışmamızda kent yönetimlerinde meydana gelen değişim Yabancılar Meclisi örneği üzerinden incelemeye tabi tutulması, geniş perspektife sahip olan kentlerde ve kent yönetimlerine meydana gelen değişimin sınırlandırılmış bir alan üzerinden aktarılması planlanmaktadır.

Çalışma kapsamında teorik ve genel bilgilendirmeler literatür üzerinden tarama yapılarak, aynı zamanda çalışmanın kapsamı içerisinde yer alan kent yönetimlerinin düzenleyicisi ve uygulayıcısı konumunda bulunan resmi aktörlerin web sayfaları üzerinden ulaşılan ve derlenen veriler kullanılarak hazırlanmıştır. Çalışmanın uygulama kısmı, kent yönetiminde yer alan yöneticiler ve Yabancılar Meclisi içerisindeki yetkililer ile mülakat yöntemiyle alan çalışması gerçekleştirilerek oluşturulmuştur. 


\section{KAVRAMSAL ÇERÇEVE}

Çalışmanın bu başlık altındaki ilk kısmında, konunun daha etkili bir şekilde ele alınması ve anlaşılırlığının arttırılması amacıyla kavramsal çerçeve oluşturulmuştur. Kavramsal açıklamaların ilk kısmında, küreselleşme, kent ve kent kültürü ve kent yönetimi kavramları ele alınmıştır. Kavramların temel belirleyicileri belirtilerek, aralarındaki ilişki ortaya konulmaya çalışılmıştır. Kavramsal açıklamaların ikinci kısmında ise, yerleşik yabancılık kavramı ele alınmış ve yönetime katılım noktasında yabancılar meclisiyle etkileşimi aktarılmıştır.

\subsection{Küreselleşme}

Küreselleşme, tarih sahnesine çok eskilerde çıkmış olan küresel kelimesinden türemiştir. Özellikle 1980 sonrası süreçten başlayarak günümüze kadar hayatımız pek çok farklı alanında yer edinen küreselleşme, zaman-mekan mefhumunda oluşmuş olan sınırların ortadan kalktığı, farklılıkların bir arada barındığı ve sürekli etkileşim içerisinde olduğu yapılar sunmaktadır. Etkileşim içerisindeki yapılar sürekli değişim ve dönüşüme tabii olmaktadır. Küreselleşmenin kazandırdığı toplumsal dinamizm çerçevesinde küreselleşmeyi anlatabilmek için pek çok farklı tanımlama yapılmıştır. Zaman ve mekan kavramının anlamını büyük ölçüde yitirdiği bir süreci ifade eden küreselleşme; ortak temelde bireylerin, malların, hizmetlerin ve fikirlerin bir yerden başka bir yere hızla hareket edebildiği küresel bir alan olarak ifade edilmektedir (Şahin, 2015:387). Küreselleşmenin hızlı bir şekilde yayılım göstermesinde, derinlemesine etki uyandırmasında gelişen teknolojinin, iletişim ve haberleşme ağlarının ve küresel ölçekteki soyut ağsal yapılarla birlikte gelen yatay, esnek örgütlenmenin büyük etkisi görülmektedir. Ayrıca küreselleşme kavramı bünyesinde sosyokültürel, ekonomik, siyasal ve yönetsel ögeler bulundurmaktadır (Özkul, 2013:123).

Küreselleşmenin sosyokültürel açıdan içinde barındırdığı özellikler ulus aşırı şirketlerin artışının ve küresel malların ortaya çıkışının sonucunda, bilgi devrimi, uydu iletişimin yayılması, telekomünikasyon ağları, bilgi teknolojisi, internet ve küresel medya şirketleri aracılı̆̆ 1 ile şekillenmiş ve yayılım göstermiştir (Heywood, 2014:191). Ayrıca küreselleşme ile ulus devlet modeli de sorgulanmaya başlanmış, tek etnikli, tek dilli, tek dinli, tek kültürlü bir ulus inşasının artık mümkün olmadığı anlaşı1mıştır (Şahin, 2015:391). Çünkü küreselleşme sonucu kentler, çeşitli göç hareketleriyle birlikte pek çok farklı milletten pek çok farklı etkenin bir arada bulunduğu alanlar olmaktadır. Sosyokültürel temeldeki bütün özellikler geniş bir etkileşim ağı içerisinde değişim ve dönüşüme uğramaktadır. Bu sosyokültürel özellikler, yalnızca kendi temellerini değil aynı zaman bireyin yer aldığı ekonomik ve siyasal ögeleri de temellendirmektedir.

Küreselleşmenin ekonomik özellikleri üzerinde bir değerlendirme yapıldığı zaman meydana getirdiği ve yayılım gösteren etkilerin para transferi üzerinden, ulus üstü ve ulus altı pek çok aktörün katılımı ile gerçekleştiği görülmektedir. Küreselleşmeyle birlikte, dünya çapında ekonomi alanında uygulanmaya başlayan neo-liberal politikalar ile açık ekonomik sistemler ve liberal stratejiler yayılım göstermiştir. Ayrıca yalnızca ekonomik alanda görülmemiş çok bu durumun boyutlu tezahürleri olmuştur (Özkul, 2013:133). Küreselleşme evvelinde ulus düzeyinde milli politikalarla sadece ulusal pazarlarda faaliyet gösterebilen ulus altı aktörler, küreselleşmeyle birlikte uluslararası piyasalara açılma firsatı elde etmiştir. $\mathrm{Bu}$ çerçevede uluslararası piyasalardaki düzeni himaye edebilmek için, uluslararası etkileşimin odak noktasında yer alan ulus üstü kuruluşlar oluşturulmuştur. Bu ulus üstü kuruluşlar genel olarak Dünya Bankası, Dünya Ticaret Örgütü, Avrupa Birliği, Uluslararası Para Fonu ve Kuzey Amerikan Serbest Ticaret Antlaşması şeklinde karşımıza çıkmaktadır. $\mathrm{Bu}$ noktada üzerinde durulması gereken konulardan birisi de; ulus üstü siyasi ve ekonomik birliklerin, anlaşmaların ve uluslararası organizasyonların oluşmasının küreselleşme sürecindeki ekonomik ve kültürel bağlantıların artmasına katkı sağlarken hükümetlerin ve ulus-devletlerin gücünün tek başına karar verilebilirliğinin azalmasına yol açtığı olarak ifade edilmektedir (Gelekçi, 2011:266).

Küreselleşmenin siyasal temeldeki özellikleri, diğer özelliklerine nazaran daha büyük öneme sahiptir. Çünkü küreselleşme ile birlikte başta insan haklarıyla ilgili konular olmak üzere mutlak egemenlik anlayışının değişmeye başladığı görülmektedir (Şahin, 2015:387). Artık yerel yönetimler, merkezi yönetimlerin çizdiği sınırlar dahilinde de olsa diğer ulusal ve ulus üstü yönetimlerle etkileşime açık sistemler haline gelerek, değişim ve dönüşüme kolay adapte olabilen yönetim kademelerini oluşturmaktadır. Bu süreçte yerel üzerinde millerce uzaklıktaki kurumların ve olayların etkisi görülebilirken, bu durum küreselleşme sürecindeki etkileşimlerle çeşitlendirilmektedir (Aslanoğlu, 2000:131). Bu anlamda ulus devletler çözülürken, kentleri de yerelleşme adı altında biçimlendirmektedir. Kentler uluslararası yapılarla doğrudan bağlantı kurabilmektedir (Güneş, 2004:1). Yerel ve ulusal düzeydeki değişimler ve bunlara bağlı olarak kentlerde meydana gelen değişimler göz önüne 
alındığında siyasal süreçler; yerel, ulusal ve küresel olayların sürekli, karşılıklı etkileşmesi anlamında hem genişlemesini hem de derinleşmesini vurgulamaktadır (Heywood, 2014:190).

Küreselleşme, kentlerin sosyokültürel, ekonomik, siyasal ve yönetsel alanlarda etkileşime açık sistemler aracılığıla yeniden şekillenmesini ve kent mekanlarının bir çok farklılığı yapısında bulundurması sonucunda yönetim anlayışındaki yenilenme ihtiyacını açıklar bir nitelik kazandırmaktadır. Küreselleşmenin getirdiğgi özellikler, kent yönetimlerinin yenilenme ihtiyacında kendini gösterir niteliktedir. Küreselleşme ile birlikte kent yönetimleri; tek bir faktörün yerini birden çok faktör aldığı, bireyin yönetim anlayışı içerisinde katılımcı olarak aktif konumda olduğu, teknolojik yeniliklerin hızla adapte olabildiği ve hiyerarşik örgütlenmelerin yerini esnek örgütlenmelerin aldığ 1 etkileşime açık sistemler olarak, değişim ve döşümü takip edebilen yapılar haline gelmektedir.

\subsection{Kent ve Kent Kültürü}

Kentler zamanın sürekliliği ile birlikte değişime uğrayarak var olmuş ve halen mevcudiyetini muhafaza etmektedir. Kentlerin mevcudiyetiyle bünyesinde barındırdığı çeşitliliğe bağlı olarak, pek çok kent tanımı ortaya çıkmıştır. Kent tanımları genellikle, köy-kent ayrımı baz alınarak ve karma ölçütler kullanılarak yerel dinamikler içerisinde değerlendirilmektedir (Keleş, 2013:102). Bu karma ölçütler iktisadi, siyasi, demografik ve sosyolojik olarak dört başlık altında incelenmektedir. İktisadi ölçütlerde kent ekonomilerinin tarıma dayalı olmaması o bölgenin kent olarak tanımlanmasında yeterli görülmekteyken siyasi ölçütlerde siyasi iktidarın demografik ve sosyolojik ölçütleri de baz alarak kenti tanımlaması yeterli görülmektedir (Şahin, 2015:3) Siyasi iktidar kentin tanımlanma alanlarını yasalar ve yasa uygulayıcıları vasıtası ile belirlemektedir. Yine kentler nüfusa bakılarak demografik ölçütlerle ve bireylerin birbirlerine yada kurumsal yapılara karşı ortaya koydukları davranış kalıpları ve yerel, ulusal ve uluslararası etkileşim dinamikleri dikkate alınarak sosyolojik ölçütlerle de ifade edilebilmektedir (Şahin, 2015:5).

Farklılıkları içinde barındıran kentler, çeşitli ölçütlerle değerlendirilse dahi, kent tanımlarında ortaya çıkan bir takım ortak diyalog noktalarının varlığı görülmektedir. Bu ortak noktalar tarımsal olmayan üretimin yapıldığı, kontrol fonksiyonlarını toplandığı, belirli büyüklük, heterojenlik ve bütünleşme düzeyine varmış mekanlar olarak ön plana çıkmaktadır (Akdiş Aslanoğlu, 2000:13). Kent Tekeli’ye göre; tarım dış1 üretim yapılan, tüm üretimin denetlendiği, dağıtımın koordine edildiği ve teknolojik yeniliklerle birlikte gelen büyüklük yoğunluk, heterojenlik, bütünleşme olgularıyla algılanan yerleşim türü olarak ve ortak diyalog noktaları üzerinden tanımlanmaktadır (2011:10). Bu zamana kadar yapılan kent tanım ve nitelikleri göz önüne alındığında kentler, birden fazla etkenin bulunduğu ve bu etkenlerin birbiriyle etkileşimlerinin süreklilik arz eden bir değişim ve dönüşüm içerisinde yeniden üretildiği alanlar olarak belirlenmiştir.

Bir yerde kent ve kentleşme olgularının varlığı bizlere o yerde kent kültürünün varlığına işaret etmektedir (Yahyagil, 2011:108). Buradan hareketle hazırlanan kavramsal çerçeve içerisinde üzerinde durulması gereken bir diğer kavram kent kültürüdür. Kent kültürünün içinde barındırdığı kültür kavramının ilk ve önde gelen özelliği bireyi yansıtmasıdır (Bektaş, 2010:100). Kent kültürü kentlerin içerisindeki geleneksel ve yabancılık unsuru barındıran çeşitliliklerle, siyasal, iktisadi, demografik ve sosyolojik ölçütlerle şekillenmektedir. Sosyolojik ölçütler, ölçütler içinde dikkatle incelenmesi gereken bir alan olarak yer almaktadır. Çünkü kent gibi büyük nüfus yoğunluğuna sahip yerleşim alanlarında bireyler (yerli-yabancı) ve bireylerle toplumsal kurumlar arasındaki sosyal ilişkiler bütünü insanların davranışlarını şekillendirip geleceğe aktarılmasında yardımcı olurken, kent kültürünü meydana getirmektedir (Yahyagil, 2011:111).

Bakıldığı zaman sosyolojik ölçütler, kent kültürünü belirleyen diğer bütün ölçütlerin temelini oluşturmaktadır. Sosyolojik ölçütler dışında hizmet sektörü ve sanayinin şekillenmesi, yerel, ulusal ve uluslararası sınırlar, oluşturulan yapılar, kent kültürünün şekillenmesinde erkileşime açik önemli alanları meydana getirmiştir. Kent kültürünün şekillenmesi, korunması ve geliştirilebilmesi için kentlerdeki kültürel etkinlikler bireyler ve kurumlar tarafindan desteklenerek, kentlerdeki çeşitli kültürel ilişkilerin kaynaştırılması gerekmektedir (Keleş, 2013:93).

Kentler ve kentlerdeki kültürel yapılar, özelliklede son dönemlerde meydana gelen ulusal ve uluslararası, bireylerin arasında ve kurumların yapısında etkileşimin artmasıyla toplumsal değişime ve dönüşüme kolay adapte olabilen yapılar olmuştur. Kentlerin böyle bir yapıya bürünmesi her türlü farklılığın bir arada bulunabileceği mekan olarak tanımlanmasına etki etmiştir. Kentler ve kent kültürü, küreselleşmeyle birlikte açık sistemler haline gelmiştir. Hem ülke içindeki diğer kentlerle hem de ülke dışındaki dünyayla sürekli etkileşime giren kentler, kültürleriyle birlikte yeniden üretilmektedir (Şahin, 2015:8). Kentler çeşitli ağ yapıları içerisinde 
YILDIRIM, Burak ve AYHAN, Bekir - Küreselleşmenin Kent Yönetimlerinde Meydana Getirdiği Değişim: Yabancılar Meclisi, Alanya Örneği

ortak bir merkez oluştururken, kent kültürleri de bu merkezleri şekillendirmekte ve şekillenen merkezlerle sürekli etkileşim sağlayarak farklılıklarla yeniden şekillenmektedir.

\subsection{Kent Yönetimi}

Dünya nüfusunun yarısından fazlasını barındıran kentler, merkezi yönetim dışında, bireylerin ortak ihtiyaçlarına ve ortak sorunlarına çözüm türetebilmek adına genellikle sınırlı sevilerde ekonomik ve idari özerkliği olan yönetimlere sahip görünmektedir. Kent yönetimi tanımları incelendiğinde kent (yerel) yönetimlerinin oluşma nedenleri 3 faktör üzerinden sıralamaktadır (Delihasanoğlu, 2013:33-34);

- İnsanların kurumsal mal, hizmet üretebilme ve tüketebilme özgürlüğ̈nü arttırması

- Hizmetlerin yerel ekonomiye ve hizmetlere uygunluğunun pratik şekilde sağlanması

- Demokrasinin etkin bir şekilde katılımı arttırarak yayılabilmesi

Genel olarak bu faktörlerin etkisi ile meydana gelmiş bulunan kent yönetimleri, uzun y1llar boyunca merkezi yönetimler karşısında varlığını korumuştur. Şüphesiz kent yönetimlerinin merkez karşısında varlığını koruyabilmelerinde en büyük etken, vatandaşların bitmek bilmeyen ihtiyaçları ve sorunlara en pratik ve en doğru yoldan çözüm bulunması isteği olarak görülmektedir. Kentlerdeki ortak sayılabilecek ve vatandaşların bitmek bilmeyen ihtiyaçlarının başında sağlıklı, güvenli, ekonomik bakımdan gelişmiş, altyapı yeterliliğine sahip, yüksek nitelikte yönetim organizasyonuna sahip olma isteği gelmektedir (Oktay, 2016:50).

Yüksek nitelikli yönetim organizasyonları içerisindeki kent yönetimlerine örnek sunulacak olunursa, öncelikle kent yönetimlerinin federal ve üniter devletlerde nasıl konumlandığı üzerinde durulması gerekmektedir. Federal devletlerde kent yönetimleri, genellikle eyaletler ve bölgeler bazında kümelenerek merkezi yönetimin katı hiyerarşisinden uzak, yasal ve ekonomik anlamda üniter devletteki kent yönetimlerinden daha da ayrıcalıkl, özerk komunda bulunmaktadır. Üniter devlerdeki kent yönetimleri ise genellikle merkezin katı hiyerarşisi altında konumlanmaktadır. Ancak küreselleşme ile birlikte ulus devletlerin sınırlarının ortadan kalkması, üniter devletlerdeki katı merkezi hiyerarşinin yumuşadığını göstermektedir. Artık üniter devletler içerisindeki tek etnikli, tek dinli, tek dilli yaşamlar ütopik bir hal almaktadır. Çünkü küreselleşme ile birlikte teknoloji, iletişim ve haberleşme ağları hızla gelişmiştir. Bunun sonucunda da uluslararası göç hareketleri hızlanmış ve kent yönetimlerinde değişikliklerin oluşması ihtiyacını doğurmuştur. İhtiyaçlar çerçevesinde üniter ve federal devletlerdeki kent yönetimleri değişmeye başlamıştır. Geçmişte üzerinde katı hiyerarşiyi barındıran kentler, artık esnek örgütlenmelere sahne olmaktadır.

Kent yönetimleri kimi zaman atama ile gelen yöneticilerin yönetiminde kimi zaman ise halkın isteği üzerine seçimle göreve gelen yöneticilerin yönetiminde bazen genel amaçlı bazen de özel amaçlı olarak kurulmaktadır. Genel amaç olarak bulunulan yörenin genel nitelikteki yerel hizmetleri ön plana çıkarken, özel amaç olarak ise sağl1k, eğitim gibi özel nitelikteki hizmetler ön plana çıkmaktadır (Özer ve Akçakaya, 2014:9-10).

Genel anlamda yukarıda çizilen çerçevede oluşan kent yönetimleri yürütme, karar ve danışma organlarından oluşmaktadır. Yürütme organları atanmış, genellikle de seçilmiş yöneticilerden ve yönetim kademelerinin çeşitli meclislerinden oluşurken karar ve danışma organları da yönetim kademelerinin seçilerek ya da atanarak belirlenmiş meclislerinden oluşmaktadır. Ancak unutulmamalıdır ki küreselleşme ile birlikte yürütme, karar ve danışma organları; bireylerin, sivil toplum aktörlerinin açık etkisi altına girmiştir. Bireyler ve sivil toplum aktörleri ile oluşan etkileşim aracılığıyla kent yönetimlerinin açık sistemler haline gelmesi ve kent yönetimlerinin geniş bir çerçevede oluşması daha hızlı ve yaygın bir şekilde gerçekleşmektedir.

\subsection{Yerleşik Yabancı Kavramı ve Yabancılar Meclisi}

Küreselleşmenin etkisi sonucunda uluslararası göç hareketlerinin hızlanmasıyla artık kentlerde birden çok etnik unsur, çeşitli ülke vatandaşları bir arada yaşamaktadır. Yerleşik yabancı kavramı, küreselleşmenin oluşturduğu etki sonucunda kentte meyana gelen değişim üzerinden tanımlanma ihtiyacı hissedilmiştir. Yerleşik yabancı kavramı ilk ifadelerini Yabancıların Yerel Düzeyde Kamusal Yaşama Katılmasına İlişkin Sözleşmesi içerisinde bulmuştur. Sözleşmenin 2. maddesinde "yerleşik yabancı" kavramı, devletin uyruğu olmayan ve bu devletin topraklarında yasal olarak ikamet eden kişi olarak tanımlanırken, aynı sözleşmede yerleşik yabancıların yerel topluluk yaşamına ve refahının gelişmesine aktif katılımını ve özellikle yerel kamu işlerine katılma imkanlarını 
artırmak yoluyla onların yerele entegrasyonunu artırmak gerektiği düşüncesine yer verilmektedir ${ }^{2}$ (Erat, 2013:280).Yerleşik yabancı kavramı, yerleşik yabancıların toplumsal entegrasyonu üzerine hazırlanan raporlarda da Avrupa Konseyi tarafından oluşturulan sözleşmelerdeki ifadeleri destekleyen nitelemelerle açıklanmıştır. Örneğin Uluslararası Stratejik Araştırmalar Kurumu (2008:13); sonradan yerleşilen ülkenin vatandaşı olmamakla birlikte, ülkeye yerleşen, yerleşilen ülkede taşınmaz sahibi olunan veya uzun süre ikameti sağlayacak kiralamalar gerçekeleştiren ve tüm bunlara bağlı olarak yılın belirli döneminde veya tamamında ülkede ikamet eden gerçek kişileri yerleşik yabancı olarak tanımlamaktadır.

Yerleşik yabancıların yerel yaşama entegrasyonu ve buna bağlı olarak kamusal yaşama katılımı üzerine oluşturulacak yapılanmalar; bireysel temelde fiziksel, psikolojik ve ruhsal etkenlerin toplumsal temeldeki mekansal (fiziki) ve sosyal (toplum temelli) bağlılıklarla bütünleşmesi sonucunda ortaya çıkmaktadır (Toprak, 2009:111). Uluslararası alanlarda yerleşik yabancıların kamusal hayata entegrasyonu üzerine oluşturulan yasal düzenlemelerde, yerleşik yabancıların katılımı için kentlerde danışma kurulu niteliğinde meclisler oluşturulması gerektiği belirtilmektedir. Oluşturulması planlanan meclisler, genel olarak Yabancılar Meclisi adı altında şekil bulmaktadır. Yabancılar meclisi adındaki bu danışma kurulları, yerleşik yabancıların kente aidiyetini arttıran ve pekiştiren, ayrıca yerel demokrasinin standartlarını yükseltme aracı olarak oluşturulan ve yabancıların yerelde karar alma sürecine aktif katılımı sağlayan kuruluşlar olarak ifade edilmektedir (Daoudov, 2015:57).

Küreselleşmeyle birlikte yerleşik yabancıların kent yönetimine dahil edilebilmesi için uluslararası kuruluşlar aracılığıyla çeşitli düzenlemeler yapılmıştır. Bu düzenlemeler ve genel anlamda "Yabancıların Yerel Düzeyde Kamusal Yaşama Katılmasına Illişkin Sözleşme"nin temel alındığı bir perspektifte hayatımıza giren yerleşik yabancı kavramı ve Yabancılar Meclisi gibi kurullar, kent yönetimlerinde ve yönetim anlayışında değişiklikler meydana getirmiştir. Değişikliklerle desteklenen çalışma alanları itibariyle yabancıların yerleşiklik temelleri oluşturulmuş ve buna bağlı olarak sosyokültürel dinamiklerden beslenen kent yönetimleri için yeni bütünleşik bir yapı oluşturmanın ilk göstergeleri sunulmuştur (Yontar, 2011:141). Böylece yerleşik yabancılar, kent yönetimindeki katılımcılığın, yerel demokrasinin artmasında kentlere yeni bir dinamizm katmaktadır. Ayrıca oluşturulan meclisler, kentlerin şekillenmesinde ve kentlerin ulusal, uluslararası alanlarda tanınırlığının artmasında önemli etkiler oluşturmaktadır. Tüm bu belirtilenler değerlendirildiğinde yerleşik yabancılar ve dolayısıyla Yabancılar Meclisi küreselleşmeyle şekillenen kent yönetimlerinde önemli bir noktada konumlanmaktadır.

Yerleşik yabancı kavramı, küresel alanlarda Avrupa Konseyi çatısı altında oluşturulan sözleşmelerle ifade edilmekte ve yine aynı sözleşmelere atıf yapılarak yerel düzeyde bütünleşme odaklı katılım mekanizmaları oluşturmaktadır. Avrupa Konseyi çatışı altındaki yerleşik yabancı çalışmaları, insanı temele alan anlayıştan beslenerek hukukun üstünlüğü ve demokratik katılım mekanizmalarının oluşturulması çabalarından beslenmektedir (Erat, 2013:281). Ancak yerleşik yabanc1 ve yabancılar meclisi gibi katılım mekanizmaları üzerine Türk yerel yönetim mevzuatında herhangi bir düzenleme bulunmamaktadır (Toprak, 2009:111). Yasal mevzuat eksikliği ve konu üzerine doğrudan çalışmaların gerçeleştirilmemiş olması, Türkiye'de yerleşik yabancılar üzerine istatistiki verilen elde edilememesi veya sağlıksız verilere ulaşılmasına sebebiyet vermektedir (Yontar, 2011:118). Yerleşik yabancılık üzerine Türk yerel yönetim yapılanması içerisinde yer alan tüm bu olumsuz gelişmelere rağmen, yerel yönetimler yabancı etkisiyle gelişen yeni etkileşimlere açık hale gelmektedir (Toprak, 2009:104). Yerleşik yabancılar ve yerel düzeyde ortaya çıkan veya çıkarılacak olan etkileşim yapıları (Yabancılar Meclisi vb.), ulusal boyutlarda ve küresel anlamda etkiler oluşturmaktadır (Toprak, 2009:99). Bu konunun Türkiye'de ve dünyada önemi artmakta ve bu odak noktasından hareketle yerel yönetim yapılanmaları içerisinde yeni politikaların geliştirilmesinin önü açılmaktadır.

\section{DÜNYADA KÜRESELLEŞME VE KENT YÖNETIMLERİ}

Kavramsal temellerin ve ilişkilerinin ortaya konulması sonrasında oluşturulan, tamamlayıcı destekler barındırdığı bu kısım başlığında, küreselleşmenin kent yönetimlerinde meydana getirdiği dünya genelindeki değişimler ve kent yönetimlerindeki değişimlerin ve yabancıların kent yönetimlerine entegrasyonunun yasal çerçevesi ortaya konulmuştur. Ayrıca yabancıların kent yönetimlerine dahil olması konusunun daha anlaşılır olması ve Alanya'daki yabancılar meclisi yapılanmasıyla kıyas oluşturulması adına, çalışma kapsamına uygun olarak belirlenen Frankfurt'daki yabancılar meclisi örneği incelenmiştir.

2 Bkz: http://kisi.deu.edu.tr/yakup.ozkaya/ (Erişim Tarihi: 18.11.2019). 
YILDIRIM, Burak ve AYHAN, Bekir - Küreselleşmenin Kent Yönetimlerinde Meydana Getirdiği Değişim: Yabancılar Meclisi, Alanya Örneği

\subsection{Küreselleşmenin Kent Yönetimlerinde Meydana Getirdiği Değişim}

Dünya 1980 sonrası süreçte küreselleşme ile birlikte büyük bir değişim ve dönüşüm içerisine girmiştir. Bu değişim ve dönüşüm, ekonomik, teknolojik, sosyokültürel, siyasi ve yönetsel alanlarda varlığını hissettirmektedir. Küreselleşmenin getirdikleriyle birlikte dünyada teknolojinin gelişimi, iletişim ve haberleşme imkanlarının yaygınlaşması artık bireylerin, düşüncelerin ve ideallerin belirli sınırlarla kısıtlı kalamadığını ve ulus devletlerin çözülmeye başladığını göstermektedir.

Ulus devletlerin artık kapalı sistemlerle tek başlarına var olamayacaklarını anlamaları, yetki ve otoritelerini yerel ve ulus üstü kuruluşlarla paylaşarak açık sistem yönetim anlayışının hakim hale geldiğini göstermektedir. $\mathrm{Bu}$ çerçevede kentler de ulus devletlerden bağımsız bir şekilde ulusal ve uluslararası kurum ve kuruluşlarla etkileşim içerisine girerek yeni yönetim organizasyonları içerisinde yer edinmektedir. Ulus devletlerin ve dolayısıyla kentlerin etkileşime dayanan değişim ve dönüşüm içerisinde açık sistemler haline gelmesi, ulus devlet içerinde yer alan yönetim anlayışındaki değişimi yansıtmaktadır. Hızla değişen ve dönüşüme uğrayan ekonomik, teknolojik, sosyokültürel, siyasal ve yönetsel alanlar karşısında kent yönetimleri hizmet kalitesini korumak ve daha ileriye taşımak için yeniden organize olmaya, kentsel problemlere yeni yönetim organizasyonları ile çözüm arayışı içine girmeye başlamıştır. Bu çözüm arayışı içerisinde meydana gelen değişim aşağıdaki şekilde sıralanmaktadır (Oktay, 2016:50);

- Merkezi yönetimler artık adem-i merkezi yönetimlerle yetki paylaşımına giderek, yönetim kademelerinde birden çok aktör karar alma ve uygulama süreçlerinde birlikte yer almaya başlamıştır.

- Kat1, dikey, hiyerarşik örgütlenmelerin yerini yumuşak, yatay, esnek örgütlenmeler almıştır.

- Hizmetler tek bir merkezden değil ihtiyaca uygun olarak ve pratik bir şekilde, hizmete en yakın birim tarafindan gerçekleştirilmektedir.

- Yönetim içerisindeki plebisit demokrasi anlayışı yerini katılımcı demokrasiye bırakmıştır.

- Kapalı ekonomik sistemler açık piyasaya dayalı rekabet anlayışıyla şekillenmeye başlamıştır.

Yönetim anlayışında meydana gelen değişimler üzerinde bir değerlendirme yapmak gerekirse; küreselleşme ile birlikte ulus devletlerin merkeziyetçi gücünün zayıflaması, yerel düzeydeki kentlerin de dünya üzerindeki diğer kentlerle daha aktif bir şekilde etkileşime girebilmesini ve kentlerde açı sistem yönetim anlayışının hakim olduğunu göstermektedir. Önceden merkezin tekelinde olan bir takım yetkiler, yerel düzeyde birey temelinde şekillenmektedir. Ulus devletin merkeziyetçiliğinin hakim olduğu dönemlerde merkezi yönetimler, kendi başına ve adına bir güç merkezi olarak görülmektedir. Bu noktada yerel yönetimler merkezin kararlarını bildirme gibi pasif görevleri üstlenmekteyken, küreselleşmeyle birlikte ulus devletlerin yerel üzerindeki etkisi zayıflamıştır. Güç ve yetki, bireyin aktif olduğu yerel alanlara kaymıştır.

Yerel düzeydeki yönetim anlayışında halkın bağımlı değişken, yöneticilerin bağımsız değişken olduğu yapılar yerini her iki tarafinda etkileşim içinde olduğu alanlara bırakmıştır (Şengül, 2001:46-47). Katılımcılığın arttı̆̆ ve serbest piyasaların hakim konuma gelerek yarışabilirliği arttırdığ 1 görülmektedir. $\mathrm{Bu}$ değerlendirmeler çerçevesinde kent yönetimi üzerine yapılan çalışmalarda kent yönetimlerinde meydana gelen değişim, yönetim alanına hakim konuma gelmiş bulunan yönetişim kavramı ile açıklanmaktadır. Yönetişim kavramı kentte yer alan tüm aktörlerin yönetim alanında, hem üretici hem tüketici konumda olduğunu göstermektedir. Yönetişim kavramı, merkezi yönetimlerin yetki ve otoritesini sivil toplumla paylaştığı, devlet otoritesi ve yaptırımlarına dayanmayan, çoğulcu yönetim biçimlerinin ve aktörlerinin etkileşimiyle katılımcı yeni bir dönemde şekillenen yap1 olarak tanımlanmaktadır (Özer ve Akçakaya, 2014:283). Kısaca yöneticinin hakim olduğu, vatandaşına aldığı kararları tebliğ eden bir yönetim anlayışının terk edildiği, katılım kanallarının çeşitlendiği yeni dönem olarak nitelendirilmektedir (Şahin, 2015:405).

Kent yönetimleri geçmişten günümüze birden çok faktörün etkisi altında şekillenmiştir. Son dönemde küreselleşmenin de etkisiyle sınırların belirsizleşmesi, ulus devlet baskısından kurtularak ulus altı ve uluslararası kuruluşlarla etkileşime girilebildiği açık sistem yönetim anlayışlarının kent yönetimlerine hakim olmaya başladığını göstermektedir. Yeni yönetim anlayışı; yönetişim kavramı çerçevesinde vatandaşların ortak ihtiyaçları ve ortak sorunlara çözüm arayışlarıyla bütün aktörlerin yönetim alanlarında aktif konumda yer aldığı, katılımın ve karşılıklı etkileşimin açık olduğu bir hal almıştır.

Kent yönetimlerinde meydana gelen değişim ve dönüşüm farklı bir ihtiyacı daha doğurmuştur. Bu ihtiyaç küreselleşmenin etkisi sonucu insanların bir yerden bir yere daha hızlı ve kolay bir şekilde meydana getirdikleri göç hareketleri ile şekillenmiş̧ir. Artık kentler tek milletten insanları değil birden çok milletten insanın barındığı alanlar olmuştur. Zamanla farklı milletten olan ve aynı kentte bulunan insanlar, bulundukları kentlerde yönetime 
katılma ihtiyacı hissetmiştir. Kent yönetimi üzerine hazırlanan yasal düzenlemeler, yabancıların kent yönetimine katılım isteği ile birlikte düzenlenmiştir. Kent yönetimi alanında yapılan çeşitli düzenlemelerle bu insanların da yönetime katılımı sağlanmaya çalışılmıştır.

\subsection{Kent Yönetimlerinde Meydana Gelen Değişimlerin Yasal Çerçevesi}

Küreselleşme ile birlikte kent yönetimlerinin özellikle yönetişim çerçevesinde girdiği değişim ve dönüşüm süreçlerinin etkin olarak gerçekleştirilebilmesi adına uluslararası ve ulus üstü bir takım kurum ve kuruluş tarafından yasal düzenlemeler yapılmaktadır. Bu uluslararası ve ulus üstü kurum ve kuruluşların en önemlileri Avrupa Birliği bünyesinde yer almaktadır. Avrupa Birliği bünyesinde yer alan bu kurum ve kuruluşların oluşturduğu yasal düzenlemelere çalışmanın bu bölümünde yer verilmektedir. Ancak hem çalışmayı daha anlaşılır kılmak, hem de çalışmanın odak noktasını kaçırmamak amacıyla bu bölümde anlatım, dünyada Yabancılar Meclisi'nin oluşumu için hazırlanmış yasal düzenlemeler üzerinde yoğunlaşmıştır. Dünyada kent yönetimlerinde meydana gelen değişimlerin yansitılabilmesi için bu çerçevede, uluslararası alanda yer verilen ve dünyanın genelinde etkileri görülen yasal düzenlemeler; Avrupa Kentsel Şartı, Avrupa Yerel Yönetimler Özerklik Şartı, Avrupa Yerel Topluluklar veya Yönetimler Arasında Sınırötesi İşbirliği Çerçeve Sözleşmesi, Gençlerin Yerel ve Bölgesel Yaşama Katılımına İlişkin Avrupa Şartı, Avrupa Ulusal Azınlıkların Korunması Çerçeve Sözleşmesi, Avrupa Ulusal Azınlıkların Korunması Çerçeve Sözleşmesi, Yabancıların Yerel Düzeyde Kamusal Yaşama Katılmasına İliş̧kin Sözleşme, yapılacak şekilde belirlenmiştir. (Keleş ve Mengi, 2013:5-6). Belirlenen düzenlemeler çalışma kapsamında farklı alt başlıklar halinde ele alınmıştır.

\subsubsection{Avrupa Kentsel Şartı}

Avrupa Kentsel Şartı 1992 yılında kabul edilmiş ve 2008 yılında Avrupa Kentli Hakları Bildirgesi olarak yeniden biçimlendirilmiştir. Avrupa Kentsel Şartı'nda halka ve kent yönetimlerine yönelik geliştirilerek, kentlerdeki yaşamın iyileştirilmesi amacıyla dört temel konu üzerinde durulmuştur. Bu konular; fiziki kentsel çevrenin iyileştirilmesi, mevcut konut stokunun iyileştirilmesi, yerleşmelerde sosyal ve kültürel olanakların yaratılması, toplumsal kalkınma ve halk katılımının özendirilmesi şeklinde sıralanmaktadır (Baş, 2017:9).

Yukarıdaki sıralamadan da anlaşılacağı üzere Avrupa Kentsel Şartı, halkın yaşayacağı coğrafi çevrenin yaşanılabilir bir yapıda geliştirilmesi, halkın sosyal ve kültürel yaşama etkin bir şekilde katılabilmesi, kentin kalkınabilmesi ve kentte bulunan halkların kent yönetimlerine aktif bir şekilde katılabilmesi amaçlarına uygun olarak kent yönetimlerine büyük sorumluluklar yüklemektedir.

\subsubsection{Avrupa Yerel Yönetimler Özerklik Şartı}

Avrupa Yerel Yönetimler Özerklik Şart1 1985 y1lında Strasburg'da düzenlenmiştir. Kent yönetimlerinin değişiminde ve gelişiminde çok önemli görülmektedir. Çünkü Yerel Yönetimler Özerklik Şartı ile demokrasinin gelişmesinde ve yönetimde etkinlik sağlanmasında temel bir konumda bulunan kent yönetimlerinin haklarının korunabilmesi için bir güvence oluşturulmuştur. Şartı onaylamış olan devletlerin kent yönetimlerinde siyasal, yönetsel ve mali yönlerden özerkliği güvence altına almaya zorlayıcı bir takım kurallar getirilmiştir (Keleş ve Mengi, 2013:77). Bu kurallar, şartı onaylamış ülkelerin ulusal mevzuatları aracılığıyla veya ülkelerin anayasalarıyla güvence altına alınması gerektiği şartın genelinde belirtilmektedir.

Avrupa Yerel Yönetimler Özerklik Şartı ile birlikte kent yönetimlerinin merkezi yönetimlerin dışında adem-i merkeziyetçi bir anlayışla şekillendiği görülmektedir. Bu şartta yer alan maddeler incelendiğinde, hizmetlerin ihtiyaca en yakın birimler tarafından gerçekleşmesi gerektiği, yerel düzeylerde katılımcılığın arttırılmasıyla demokrasinin geliştirilmesi ve yayılması gerektiği, dolayısıyla kent yönetimlerinin yeniden şekillenesi gerektiği anlaşılmaktadır. Ayrıca kent yönetimlerinin düzenlemesi yapılırken veya her hangi bir değişiklik planlandığı zamanlarda, kent yönetimlerine katılan yerel aktörlerin görüş ve fikirlerinin alınması gerektiği ve düzenlemelerin, değişikliklerin bu aktörler aracılığı ile gerçekleşmesi gerektiği belirtilmiştir. Kent yönetimlerinde değişimleri ve dönüşümleri hedefleyen şarta, Türkiye taraf olmakla birlikte bir çok maddesine çekinceme koymuştur.

\subsubsection{Avrupa Yerel Topluluklar veya Yönetimler Arasında Sınırötesi İşbirliği Çerçeve Sözleşmesi}

Avrupa Yerel Topluluklar veya Yönetimler Arasında Sınırötesi İşbirliği Çerçeve Sözleşmesi, Avrupa Birliği tarafindan 1980 yılında oluşturulmuştur. Bu sözleşmenin oluşturulmasındaki temel amaç yerel düzeydeki topluluklar ve kent yönetimlerinin ulusal ve uluslararası alanda diğer topluluk ve kent yönetimleri ile ortak amaçlar ve benzer sorunlara çözüm geliştirmek için işbirliği içine girebilmelerine imkan sağlamaktır. Bu sözleşme ile artık kentler ve kent yönetimleri birbirlerini sosyokültürel, ekonomik siyasal ve yönetsel anlamda 
YILDIRIM, Burak ve AYHAN, Bekir - Küreselleşmenin Kent Yönetimlerinde Meydana Getirdiği Değişim: Yabancılar Meclisi, Alanya Örneği

etkileyebilmektedir. Kent yönetimlerinin yeniden dizayn edilmesinde kentlerin bu ve bunun gibi sözleşmeler aracıllğıyla ve küreselleşmenin de etkisiyle etkileşime açık sistemler haline gelmesi önemli bir nokta oluşturulmaktadır ${ }^{3}$. Bu sözleşme dahilinde oluşturulmuş sınır ötesi işbirliklerine en güzel örneği kardeş şehir uygulamaları oluşturmaktadır. Bu uygulamalar vasıtası ile etkileşime giren kentler, uygulamaları etkin bir şekilde geliştirebildikleri zaman kent yönetimlerinde etkin bir değişiklik olduğu gözlemlenebilmektedir.

Avrupa Yerel Topluluklar veya Yönetimler Arasında Sınırötesi İşbirliği Çerçeve Sözleşmesi, Türkiye tarafından 1998 yılında imzalanmıştır. Ancak 2000 yılında onaylanmış olan 4571 sayılı Avrupa Yerel Topluluklar veya Yönetimler Arasında Sını̈ötesi İşbirliği Çerçeve Sözleşmesinin Onaylanmasına Dair Kanun ile 24045 (Mükerrer) sayılı resmi gazetede yayınlanarak yürürlüğe girmiştir.

\subsubsection{Gençlerin Yerel ve Bölgesel Yaşama Katılımına İlişkin Avrupa Şartı}

Gençlerin Yerel ve Bölgesel Yaşama Katılımına İlişkin Avrupa Şartı, 1992 yılında kabul edilmiş ve 2002-2003 yıllarında revize edilerek geliştirilmiştir. Şartın amacı, gençlerin yaşadıkları kentlerde ve bölgelerdeki kent yaşamına ilişin her türlü toplumsal katılım firsatlarından yararlanmaları ve demokratik yaşamın geliştirilmesinde önemli roller üstlenmeleri için gerekli yasal düzenlemelerin yapılmasının sağlanması olarak belirlenmiştir (Keleş ve Mengi, 2013:95). Bu şart gençlerin kent yönetiminde aktif olarak katıldığı ve gerekirse çeşitli örgütsel kuruluşlarla oluşturulan yeni yönetim kademeleriyle işlerlik kazandığı imkanlar sunmaktadır. Kent yönetimleri de gençlerin katılımı ile daha dinamik yönetim anlayışının hakim olduğu, katılımın dolayısıyla demokrasinin yaygınlaştığı, değişim ve dönüşüme hızla adapte olabilen yapılar oluşturmaktadır.

\subsubsection{Avrupa Ulusal Azınlıkların Korunması Çerçeve Sözleşmesi}

Avrupa Ulusal Azınlıkların Korunması Çerçeve Sözleşmesi, ulusal sınırlar içerisindeki azınlık haklarının korunması adına uluslararası kuruluşlar vasıtası ile oluşturulmuş sözleşmeler arasında yer almaktadır. Kendisine amaç olarak, ulusal azınlıkların ve azınlıklar içerisinde yer alan aktörlerin hak ve özgürlüklerinin korunmasını belirlenerek, 1995 'te kabul edilmiş ve 1998 'de yürürlüğe girmiştir. Ancak bu noktada yapılan düzenlemeler ulusal sınırlar içerisinde değişikliklere sebebiyet verebileceği kanısı ile hassas niteliklerle şekillendirilmeye çalışılmıştır. Yapılan düzenlemeler toprak bütünlügüne ve egemenlik haklarına saygı gösterilerek oluşturulmuştur. Sözleşme çerçevesinde yapılan düzenlemeler, hiç şüphesiz kent yönetimlerinin şekillenmesinde de etki etmiştir. Devlet yapısı ve geleneği düşünüldügünde Türkiye'nin bu düzenlemeye taraf olmadığı görülmektedir (Keleş ve Mengi, 2013:87-88).

\subsubsection{Avrupa Bölge ve Azınlık Dilleri Şartı}

Avrupa Bölge ve Azınlık Dilleri Şartı, dünya üzerinde ulusal sınırlar içerisinde azınlıkların unutulmaya yüz tutmuş dillerinin korunması, kamusal ve özel alanda kullanım hakkı tanınması amacıyla 1992 yılında kabul edilmiş ve 1998 yılında yürürlüğe girmiştir. Kent yönetimlerin de yapılan değişimlerde bu konu üzerinde de değişimin söz konusu olması gerektiği vurgulanmaktadır. Türkiye bu şarta da taraf değildir (Keleş ve Mengi, 2013:88-89).

\subsubsection{Yabancıların Yerel Düzeyde Kamusal Yaşama Katılmasına İlişkin Sözleşme}

Yabancıların Yerel Düzeyde Kamusal Yaşama Katılmasına İlişkin Sözleşme, çalışmamızın asıl konusunu oluşturan ve kent yönetimlerinde yabancıların da katılımının sağlanması amacıyla çeşitli dernek, vakıf, sendika ve meclislerin kurulması için uluslararası düzeyde, Avrupa Birliği bünyesinde oluşturulmuştur. Temel insan haklarına dayalı olarak, ekonomik ve sosyal geliş̧meyi göz önünde bulundurarak, yabancıların yereldeki vatandaşların sahip olduğu haklara sahip olmaları ve bu yolla yabancıların yerel topluluklarla bütünleşmeleri amaciyla 1992 y1lında imzalanan sözleşme, 3 bölüm ve 19 maddeden oluşmaktadır ${ }^{4}$. Sözleşmenin ilk bölümde ifade, toplanma ve dernek kurma özgürlükleri üzerinden, yerleşik yabancıların da özgürlüklerden yararlanması gerektiğinden bahsederken; sözleşmenin ikinci bölümünde çalışmamızın da odak noktasında yer alan yerleşik yabancıların yerel düzeyde temsil edebilmesi adına danışma organlarının kurulması gerektiği yönünden bahseden maddeler yer almaktadır. Sözleşmenin son bölümde de yerleşik yabancıların yerel yönetim seçimlerinde seçme ve seçilme hakkını kullanabilmeleri üzere düzenlenmiş maddeler yer almaktadır ${ }^{5}$.

\section{Bkz:}

https://www.tbmm.gov.tr/tutanaklar/KANUNLAR_KARARLAR/kanuntbmmc084/kanuntbmmc084/kanuntbmmc0840 4517.pdf (Erişim Tarihi: 18.11.2019).

4 Bkz.: http://www.migm.gov.tr/avrupa-konseyi (Erişim Tarihi: 27.11.2017).

5 Bkz.: http://kisi.deu.edu.tr/yakup.ozkaya/ (Erişim Tarihi: 18.11.2019). 
Yabancıların Yerel Düzeyde Kamusal Yaşama Katılmasına İlişkin Sözleşmeye göre; yerleşik yabancıların bulunduğu kent yönetimleri, yerleşik yabancıların da ülkenin kendi vatandaşlarıymış gibi çeşitli hak ve özgürlüklerden yararlanması gerektiği yönünde düzenlemelere yer verilerek değişime uğramaktadır. Kent yönetimlerindeki değişimle birlikte yerleşik yabancılar kendi istekleriyle kent yönetimlerine katılabilmek ve kent yönetimi ile sürekli iletişim halinde kalabilmek adına dernek, sendika, vakıf ve meclisler şeklinde örgütlenmektedir. Yabancıların bu şekillerde örgütlenmesinde değişime uğramış kent yönetimlerinin etkisi görmezden gelinememektedir. Sözleşme çerçevesinde sözleşmeyi imzalayan ülkelerin kent yönetimlerinde yabancıların da katılımının sağlanabilmesi için Yabancılar Meclisi oluşturulmuştur. Oluşturulan meclis kent yönetimlerinde genel olarak danışma organı olarak yer almaktadır. Bir danışma organı olarak kurulmuş olan meclislerin üyeleri çeşitli milletlerden vatandaşlardan oluşmaktadır. Bu kolektif meclisler kent yönetimlerinde etkin konumda olarak hem kendi haklarını savunmakta hem de kentlerin gelişmesine katkıda bulunmaktadır.

Türkiye yabancıların kamusal yaşama katılımına ilişkin olan Avrupa Konseyi tarafından oluşturulan bu sözleşmeye taraf olmamıştır. Ancak ülkenin bazı bölgelerinde bu anlaşanın çizdiği sınırlar ile örtüşen niteliklere sahip olarak oluşturulmuş dernek, sendika gibi kurum ve kuruluşları görülmektedir.

\subsection{Dünyadan Yabancılar Meclisi Uygulaması Örneği: Frankfurt Yabancılar Meclisi (KAV)}

Dünyada küreselleşmenin de etkisi ile oluşturulan yasal düzenlemeler çerçevesinde kentlerde danışma kurulu niteliğinde meclisler oluşturularak, yerleşik yabancı vatandaşların kent yönetimine katılımı sağlanmaktadır. Frankfurt'ta yer alan Yabancılar Meclisi de danışma kurulu niteliğindeki bu meclislere örnek teşkil etmektedir. Çalışmanın bu bölümünde dünyadan Yabancılar Meclisi'ne Frankfurt Yabancilar Meclisi'nin örnek seçilmesi; Alanya' da yerleşik olarak yaşayan yabancıların büyük bir kısmının Alman uyruklu olmasından kaynaklanmıştır.

Danışma kurulu niteliğindeki Frankfurt Yabancılar Meclisi, Frankfurt am Main şehrinin yabancı nüfusunun en az 3 en fazla 37 üyesinden oluşurken, üyeler arasında yabancı uyruklu vatandaşların yanında çeşitli dernek, vakıf, sendika üyeleri ve milletvekilleri yer alabilmektedir ${ }^{6}$. Yabancilar Meclisi üyeleri genel olarak yabancilar tarafindan, beş yıllığına ücretsiz, eşit, gizli ve doğrudan seçimlerden seçilirken seçim prosedürü Hessen Belediye Seçim Yasası tarafından düzenlenmektedir. Yasa çerçevesinde belli bir süredir kentte yaşayan ve 18 yaşını doldurmuş vatandaşlar oy kullanabilmektedir ${ }^{7}$. Yabancılar Meclisi'nin başkanı seçimden sonraki ilk hafta içerisinde yapılan toplantıda meclis üyeleri arasından seçilmektedir ${ }^{8}$. Alanya'daki Yabancılar Meclisi gibi danışma kurulu niteliğinde olan ve yerleşik yabancıların sorunlarına çözün getirebilmek, yerli ve yabancı sakinlerinin birlikteliğini geliştirerek sosyal, kültürel, politik ve ekonomik yaşamda yabancı sakinlerinin katılımını teşvik etmek amacıyla kurulan Frankfurt Yabancılar Meclisi, ulusal ve uluslararası düzenlemeler çerçevesinde yasal dayanaklar üzerine kurulmuştur. Meclise katılım kent genelinde yabancı vatandaşlarca yapılan ciddi bir seçim sonucunda belirlenmektedir. Ayrıca Frankfurt Yabancılar Meclisi faaliyetlerini her ay düzenli olarak gerçekleştirdikleri olağan toplantılarında planlamaktadır. Meclis toplantılarda çeşitli konularla ilgili tavsiye kararlar almaktadır?.

Frankfurt Yabancılar Meclisi üzerinden bir değerlendirme yapılarak, uluslararası kuruluşlara ve onların çıkardığı düzenlemelere taraf olan ülkelerdeki yerleşik yabancılar için oluşturulmuş düzenlemelerin ve kuruluşların Frankfurt Yabancılar Meclisi’ne benzer niteliklerde oluştuğu yargısını çıkarmak mümkün görünmektedir. Ayrıca Frankfurt Yabancılar Meclisi incelendiğinde, çalışmanın ileriki bölümünde aktarılacak olan Alanya Yabancılar Meclisi'yle benzerlikler barındırmakla birlikte, pek çok farklılığı da barındırdığı görülmektedir.

\section{KÜRESELLEŞME'NIN TÜRKIYE'DE KENT YÖNETIMII ÜZERINDEKİ ETKILLEṘ}

Çalışmanın bu bölümünde, küreselleşmenin Türkiye'de ve özellikle kentlerde meydana getirdiği değişikliklerle birlikte, kentlerin küresel değişim dinamikleriyle desteklenerek oluşturulacak yönetsel yapılara evirilmesindeki süreçler aktarılmıştır. Ayrıca kent yönetimlerinin Türkiye'deki değişimi, anayasal ve yasal desteklerle ortaya konulmuştur. $\mathrm{Bu}$ çerçevede aktarılan bilgiler, yabancılar meclisinin Alanya'da gerçekleştirilen örneğinin incelenmesini evvelinde tamamlayıcı bir alt metnin oluşturulması amaçlanmıştır.

6 Bkz.: https://www.frankfurt.de/sixcms/detail.php?id=2896\&_ffmpar[_id_inhalt]=176450 (Erişim Tarihi: 18.11.2019).

7 Bkz.: https://www.frankfurt.de/sixcms/detail.php?id=2896\&_ffmpar[_id_inhalt]=176449 (Erişim Tarihi: 18.11.2019).

8 Bkz.: https://www.frankfurt.de/sixcms/detail.php?id=2896\&_ffmpar[_id_inhalt]=176453 (Erişim Tarihi: 18.11.2019).

9 Bkz.: https://www.frankfurt.de/sixcms/detail.php?id=2896\&_ffmpar[_id_inhalt]=176449 (Erişim Tarihi: 18.11.2019). 


\subsection{Küreselleşme ve Kent Yönetimlerinde Meydana Gelen Değişim}

1980 sonrasında dünyaya hakim olan küreselleşme hareketleri, Türkiye'de de yansımalarını bulmaktadır. Bu dönemde geliştirilen neo-liberal politikalarla siyasal, ekonomik ve yönetsel sistemler dışarıya karşı olan katı kapalı yapılarından kurtularak, sürekli değişim ve dönüşüme tabi olan etkileşime açık sitemler haline gelmeye başlamıştır. Türkiye'de yaşadığımız değişim en belirgin örnekleri, yerelle küresel olanın karşılaştığı noktada kentlerde kent yönetimlerinde gerçekleştiği görülmektedir (Ökmen ve Parlak, 2008:241). Kentlerin aç1k sistemler haline gelmesinde etkili olan küreselleşme hareketleri, Türkiye'de Avrupa Birliği programına uyum kapsamında uygulanmaya çalışılan politikalardan da destek bularak şekillenmektedir.

Türkiye'de Avrupa Birliği politikalarıla takip edilen süreçte, merkezi yönetimlerin yetki ve otoritelerini yerel yönetimlerle paylaşmaya başladığı görülmektedir. Ancak merkezi yönetimler tarafindan yetkilerin ve otoritenin yerelle paylaşılması bizlerde, merkezi yönetimin devlete, yerel yönetimin topluma ait olduğu düşüncesini değil, merkezi ve yerel yönetimleri bir bütün olarak toplumun oluşturduğu ve yerel yönetimlerin demokrasinin beşiği olduğu düşüncesini oluşturması gerekmektedir (Güler, 2013:15). Bu düşünceler ve küreselleşmenin etkileriyle şekillenen kent yönetimlerinin aktörleri, sadece ulus devlet ve yerel yönetimler olarak açıklanamamaktadır. Türkiye'de kent yönetimleri artık sadece ulus devletin iç dinamikleri tarafından değil, aynı zamanda giderek artan biçimde uluslararası dinamiklerin ve siyasal dengelerin yapılarıyla şekillenmektedir (Şengül, 2001:96).

Türkiye'de değişime uğrayan kent yönetimleri, küreselleşmenin de etkisiyle dünyada modern batı kentleri olarak nitelendirilen kentlerin özelliklerine sahip olabilmek adına sürekli değişim dönüşüm içerisine girmiştir. Süreç içerisinde kentlerin farklı kimlikleri, ruhu ve estetiğinin o kentte yaşayan vatandaşların kent yönetimlerine aktif olarak katılımı ile korunması gerektiği düşüncesi, kent yönetimlerinin bu yönde şekillenmesine sebebiyet vermektedir (Ökmen ve Parlak, 2008:244). Kent yönetimleri birden çok aktörün aktif katılımına sahne olarak demokrasinin beşiği konumunda ve hizmetin ihtiyaca en yakın birimler tarafından gerçekleştirilmesi üzerine kurgulanmıştır. Küreselleşmeyle birlikte değişime uğrayan kent yönetimlerini sadece demokratikleşme ve hizmette yerellik üzerine anlatmak, konunun eksik kalmasına yol açmaktadır. Çünkü kent yönetimlerindeki değişim, kent yönetimlerinin yerel tarafından yerine getirileceğini belirtirken dışarıdan gelecek olan yatırımların kente çekilebilmesi küresel düzeyde amaçlar gütmektedir. Artık yerel sadece halk için değil küresel için düşüncesi ile kent yönetimleri yarışan yerellikler üzerine meydana gelen rekabette, yarışı "küresel düşünüp yerel yaşamak" mottosu ile yürütmektedir (Güler, 2013:12).

Türkiye'de küreselleşmeyle değişime uğramış kentlerin özellikleri göz önünde bulundurulduğunda, kent yönetimlerinin yönetişim kavramını bünyesinde barındırdığı açık bir şekilde görülmektedir. Bu noktada kent yönetimlerinin değişiminde yönetim kavramının yerini yönetişim kavramının almasını, ikisinin arasındaki ayrım ortaya konularak açıklamakta fayda görülmektedir. Üniter devlet yapısına sahip olan Türkiye'de yönetim kavramı değişime uğramadan önce devlet aygıtı üzerinden yerine getirilirken, değişim sonrasında yönetimde sadece devlet değil, devletin dışında tanımlanan piyasa ve sivil toplum alanında faaliyet gösteren örgütlerin de yer aldığ1 görülmektedir (Şengül, 2001:112).

Türkiye'de güncel olarak kent yönetimleri merkezin taşra uzantıları olarak il ve ilçe yönetimi, yerel yönetim birimleri olarak da il özel idaresi, belediye ve köy yönetimleri şeklinde ayrılmaktadır. Ayrıca bunların dışında ve bunlar yardımcı olabilmek adına çeşitli sivil toplum kuruluşları da yer almaktadır. Tüm bu örgütlenme şeması içerisinde yer alan aktörler yürütme, karar ve danışma organları olarak nitelendirilmektedir. Ayrıca yerel halkın kent yönetimlerine aktif bir şekilde katılımlarının sağlanabilmesi adına kent konseyleri gibi çeşitli meclisler oluşturulmuştur. Kent konseyleri dışında halkın kendilerinin oluşturduğu gönüllü dernek, sendika, vakıf ve çeşitli sivil toplum kuruluşlarıyla kent yönetimlerine katılım sağlanabilmektedir.

Genel olarak şimdiki bölüm üzerine yapılacak bir değerlendirme, Türkiye'de kent yönetimlerinin etkilere, değişime ve katılıma açık sistemlerle şekillendiğini göstermektedir. Küreselleşmenin etkisiyle şekillenen kentlerdeki yönetim örgütlenmelerinin, küresel aktörlerin dikkatini çekebilmek amacıyla yerel yapılardan beslenilerek oluşturulduğu görülmektedir. Türkiye'de küreselleşmeyle birlikte değişime uğramış olan güncel kent yönetimlerinin yasal çerçevesi, tarihsel değişim süreçleriyle birlikte değerlendirilerek anayasal ve yasal düzenlemeler üzerinden bir sonraki başlık altında aktarılmıştır. 


\subsection{Kent Yönetiminde Meydana Gelen Değişimin Anayasal ve Yasal Çerçevesi}

Türkiye'de küreselleşmenin kentlerde meydana getirdiği değişimle birlikte kent yönetimleri de değişime uğramaya başlamıştır. Kent yönetimlerinde meydana gelen değişim, Avrupa Birliği bünyesinde bulunan organlar ve birimler tarafindan oluşturulan yasal düzenlemelerle uyumlu olacak şekilde, Avrupa Birliği politikaları ile paralel çizgide gelişmiştir. Avrupa Birliği bu konuda Türkiye'nin yapacağı yasal düzenlemelerden beklentilerini, bölgesel politika ve yapısal araçların koordinasyonu başlı̆̆ı altında, kamu yönetimi çerçevesinde dile getirmektedir. Beklentilerin takibi, ilerleme raporları ve katılım ortaklığı belgeleri üzerinden yapılmaktadır (Mengi, 2007:103-104).

Türkiye Avrupa Birliği bünyesinde oluşturulan düzenlemelerden; Gençlerin Yerel ve Bölgesel Yaşama Katılımına İliş̧kin Avrupa Şartına, Avrupa Ulusal Azınlıkların Korunması Çerçeve Sözleşmesine, Avrupa Bölge ve Azınlık Dilleri Şartına, Yabancıların Yerel Düzeyde Kamusal Yaşama Katılmasına İlişkin Sözleşmesine taraf değildir. $\mathrm{Bu}$ sözleşmelere taraf olmamakla birlikte bu düzenlemeler çerçevesinde yapılanların takipçisi konumunda yer almaktadır. Bunların içerinden Yabancıların Yerel Düzeyde Kamusal Yaşama Katılmasına İlişkin Sözleşmesine de taraf olmamasına rağmen sözleşmenin şartları çerçevesinde oluşturulması planlanan yabancılar meclisi uygulamasına Alanya'da bir örnek oluşturması, takipçiliğinin en büyük göstergesi olarak görülmektedir.

Türkiye Avrupa Kentsel Şartına ve Avrupa Yerel Yönetimler Özerklik Şartına imza atarak, şartlar doğrultusunda kent yönetimlerini şekillendirmeye gayret etmektedir. Avrupa Birliği de bu şartların yerine getirilip getirilmediğinin s1kı takipçiliğiyle denetlemektedir. Son olarak Avrupa Yerel Topluluklar veya Yönetimler Arasında Sınırötesi İşbirliği Çerçeve Sözleşmesi, kent yönetimlerini şekillendirirken Türkiye'nin de imzaladığı ve şartlarını yerine getirmek için çabaladığı düzenlemeler içerisinde yer almıştır. Türkiye bu sözleşmeyi 1998 yılında imzalamış, 10.05.2000 tarih ve 240458 (Mükerrer) sayılı resmi gazetede yayınlanan 4571 sayılı Avrupa Yerel Topluluklar veya Yönetimler Arasında Sınırötesi İşbirliği Çerçeve Sözleşmesinin Onaylanmasına Dair Kanun ile onaylayarak, o günden bu güne dünyanın pek çok kenti ile ortaklık ilişkilerini geliştirmiştir.

Türkiye'de küreselleşme ile birlikte değişime uğramış mevcut kent yönetimlerinin yasal düzenlemelerini oluşturan mevcut genel kanunlar aşağıdaki gibi sıralanabilmektedir;

- Büyükşehir Belediye Kanunu (5216 sayıl1)

- İl Özel İdaresi Kanunu (5302 say111)

- Mahalli İdare Birlikleri Hakkında Kanun (5355 sayılı)

- Belediye Kanunu (5393 say11)

- On Dört İlde Büyükşehir Belediyesi ve Yirmi Yedi İlçe Kurulması İle Bazı Kanun ve Kanun Hükmünde Kararnamelerde Değişiklik Yapılmasına Dair Kanun (6360 sayılı)

- Yabanc1lar ve Uluslararası Koruma Kanunu (6458 say111)

Tüm bu yasal sınırlar çerçevesinde Türkiye'de kent yönetimleri, 1982 anayasasının 126. maddesinde merkezi yönetimin taşra uzantısı şeklinde örgütlenen kent yönetimlerinin nasıl kademelendiğini belirtilmektedir. 9.11.1982 tarih ve 17863 (Mükerrer) sayı ile resmi gazetede yayınlanan Türkiye Cumhuriyeti Anayasası md.126:

"Türkiye, merkezi idare kuruluşu bakımından, coğrafya durumuna, ekonomik şartlara ve kamu hizmetlerinin gereklerine göre, illere; iller de diğer kademeli bölümlere ayrllır. Illlerin idaresi yetki genişliği esasına dayanır. Kamu hizmetlerinin görülmesinde verim ve uyum sağlamak amactyla, birden çok ili içine alan merkezi idare teşkilatı kurulabilir. Bu teşkilatın görev ve yetkileri kanunla düzenlenir".

Yine 1982 anayasasının 127. maddesinde kent yönetimlerinin yerel düzeyde örgütlenme kademelerinden bahsedilmektedir. 9.11.1982 tarih ve 17863 (Mükerrer) sayı ile resmi gazetede yayınlanan Türkiye Cumhuriyeti Anayasası md. 127;

"Mahalli idareler; il, belediye veya köy halkının mahalli müşterek ihtiyaçlarını karşılamak üzere kuruluş esasları kanunla belirtilen ve karar organları, gene kanunda gösterilen, seçmenler 
tarafindan seçilerek oluşturulan kamu tüzelkişileridir. Mahalli idarelerin kuruluş ve görevleri ile yetkileri, yerinden yönetim ilkesine uygun olarak kanunla düzenlenir”.

Türkiye'de kent yönetimlerinin yasal çerçevesi incelendiğinde, kent yönetimlerinde bölge düzeyinde örgütlenmelere rastlanmamaktadır. Türk kent yönetimleri bu yasal sınırlar dahilinde yürütme, karar, danışma meclislerinden ve halkın katılımının sağlanabilmesi için halk tarafından oluşturulmuş çeşitli meclislerden oluşmaktadır. Son dönemlerde Türkiye'de en fazla yabancının yaşadığı kentlerden biri olan Alanya'da, kentteki yabancıların da yönetime katılmaları için danışma kurulu niteliğinde olan "Yabancılar Meclisi" oluşturulmuştur. Dünya'da yabancılar meclisi, oluşumunun temellerini Yabancıların Yerel Düzeyde Kamusal Yaşama Katılmasına İlişkin Sözleşmeden almaktadır. Türkiye'nin bu sözleşmeye taraf olmamasına karşın bu sözleşme temelinde planlanan Yabancılar Meclisi'nin oluşturulması, çalışmanın araştırma konusunu oluşturmaktadır. Ayrıca 11.04.2013 tarih ve 28615 (Mükerrer) sayı ile resmi gazetede yayınlanan, Yabancılar ve Uluslararası Koruma Kanununun 96. maddesinin 3. fikrasında şu şekilde bahsedilmektedir;

\begin{abstract}
"Kamusal ve özel mal ve hizmetlerden yararlanma, eğitime ve ekonomik faaliyetlere erişim, sosyal ve kültürel iletişim, temel sağllk hizmeti alma gibi konularda kurslar, uzaktan eğitim ve benzeri sistemlerle tanitım ve bilgilendirme etkinlikleri Genel Müdürlükçe, kamu kurum ve kuruluşları ile sivil toplum kuruluşlarıyla da iş birliği yapılarak yaygınlaştırılı’”.
\end{abstract}

$\mathrm{Bu}$ şekilde çıkarılmış bulunan ve yabancıların uyumunu sağlamaya yönelik faaliyetleri geliştirmek amacında bulunan kanunlar ve oluşturulan kurum ve kuruluşlar, Türkiye'de de yayılım göstermeye başlamıştır. Doğrudan bir düzenleme olmamakla birlikte çalışmanın konusunu oluşturan yabancılar meclisi, oluşumu, yapısı, meclis kompozisyonu, amaçları ve çalışma alanları yukarıda ifade edilen temel düzenlemeler çerçevesinden destek bularak gerçekleştirmektedir.

\title{
5. KÜRESELLEŞMENIN ALANYA’DAKİ ETKİSI: YABANCILAR MECLİSİ ÖRNEĞİ
}

Çalışmanın son bölümü olarak ele alınan başlık altında, küreselleşmenin dolaylı etkileri sonucunda Alanya ve kentin yönetiminde meydana gelen değişim; Alanya'da yerleşik olarak bulunan yabanciların oluşturduğu "Alanya Belediyesi Yabancılar Meclisi" uygulaması örnek sunularak ortaya konulmaya çalışılmıştır.

\subsection{Alanya ve Kent Yönetimi Hakkında Genel Bilgiler}

Alanya, küreselleşmenin de etkisiyle birlikte etkileşime açık, değişim ve dönüşüme kolay adapte olabilen kent yapısı ve oluşturulan kent kültürü ile bir çok kente örnek teşkil eden bir konumda yer almaktadır. Ekonomisinde turizm sektörünün hakimiyetinin görüldügü̈, yaz-kış yapılan sosyal ve kültürel etkinlikler aracıllğ ile Antalya'ya gelen turistlerin \%30'unun Alanya'da konakladığı düşünüldüğünde, yılda ortalama 2.500.000 üzerinde yabancı misafire ev sahipliği yapmaktadır ${ }^{10}$. Ayrıca 99 milletten tatil amaçlı gelen yabancı misafirlerin dışında nüfusu içerisinde yer alan 79 milletten insanla medeniyetlerin, dillerin, dinlerin birleştiği bir kültürel çeşitliliği de bünyesinde barındırmaktadır (Yücel, 2018:Kişisel Görüşme). Alanya'da yabancı uyruklu vatandaşların 40.000 üzerinde mülke sahip olduğu bilinmektedir (Bolat, 2018:Kişisel Görüşme). 17.000'in üzerinde yabancı uyruklu yerleşik vatandaş yaşamaktadır (Yücel, 2018:Kişisel Görüşme). Yerleşik yabancıların 15.000 'den fazlası, Avrupalı vatandaşlardan oluşmaktadır ${ }^{11}$. Alanya'da yerleşik olarak bu kadar çok yabancının bulunması ve sürekli yabancı vatandaşların ziyaretlerinin gerçekleştiği bir kent olması, kent yönetiminin de bu doğrultuda yeniden şekillenmesine sebebiyet vermektedir.

Küreselleşmenin dolaylı etkileri sonucu ve kent yönetimlerine yönetişim anlayışının hakim olmaya başlamasıyla, yerel halkın yönetime katılımının sağlanması için kent konseyi çatısı altında çeşitli meclisler oluşturulmuştur. Ayrıca Alanya da yerleşik olarak yaşayan yabancıların katılımını arttırabilmek ve kentin şekillenmesinde, gelişmesinde katkıda bulunabilmek adına Türkiye'de ilk ve tek örnek olarak "Alanya Belediyesi Yabancılar Meclisi" adında, danışma kurulu niteliğinde bir meclis oluşturulmuştur. Alanya Belediyesi Yabancılar Meclisi kent konseyi içerisinde yer almamaktadır. Kurulduğunda Turizm ve Halkla İlişkiler Müdürlüğü çatısı altında bulunan meclis, şuanda Belediye Başkanının doğal üye olarak başkanlığını yaptığı doğrudan bir bağlantıyla Belediye Başkanlığı makamı ile ilişkilendirmek, dolaysıyla Özel Kalem Müdürlüğü çatısı altındaki bir konumda değerlendirmek mümkündür (Bolat, 2018:Kişisel Görüşme). Alanya

10 Bkz.: http://www.alanya.gov.tr/alanyada-turizm1 (Erişim Tarihi: 18.11.2019).

11 Bkz.: http://alanyakentkonseyi.org.tr/S/54/Rakamlarla-Alanya (Erişim Tarihi: 18.11.2019). 
mevcut sosyokültürel yapıs1, yönetsel-siyasal sistemi ve ekonomik düzeni itibariyle Türkiye ve dünyadan pek çok kente ve kent yönetimine örnek teşkil eden bir konumda yer almaktadır.

\subsection{Alanya Belediyesi Yabancılar Meclisi}

Dünya genelindeki yeni yerel yönetim yapıları içerisinde yer alan yabancılar meclisinin, Alanya'daki "Alanya Belediyesi Yabancilar Meclisi” örneği üzerinden bu başlık altında incelenmesiyle küreselleşmenin kent yönetimlerine etkisinin ortaya konulması amaçlanmıştır. $\mathrm{Bu}$ çerçevede, Alanya Belediyesi Yabancılar Meclisi'nin hangi amaçla, nasıl kurulduğu, mevcut yapısı, üye kompozisyonu ve faaliyetleri aktarılmıştır. Aktarılan bilgiler sonrasında yapılan değerlendirmeler sonucunda, yerleşik yabancıların ve yabancılar meclisinin Alanya'da kent kültürü ve yönetimi alanında meydana getirdiği değişiklikler belirtilerek, çalışma sonuçlandırılmıştır.

\subsubsection{Meclisin Kuruluşu ve Meclise Üyelik}

Yabancılar Meclisi, yerleşik yabancı toplulukların kente aidiyeti oluşturma ve pekiştirme, kent kültürünü geliştirme, ayrıca yerel demokrasinin standartlarını yükseltme ve katılımı arttırma aracı olarak, yabancıların yerelde karar alma sürecine aktif katılımı sağlamak adına kurumsallaştırılmış bir danışma organı olarak nitelendirilmektedir (Daoudov, 2015:57). Alanya 'da kurulan Yabancılar Meclisi öncelikli amaç olarak, yerleşik yabancılarla kent yönetimi arasında iletişim kurulmasını sağlayarak yerleşik yabancıların kente uyumunun sağlanması ve yerel düzeyde kentin yönetimine katılımının arttırılması düşüncesiyle oluşturulmuştur. Yabancılar Meclisi kente uyumunun sağlanması ve yabancıların sorunlarını yerele, kamuya, kurumlara ve sivil toplum örgütlerine iletmek maksadıyla arada bir köprü görevi görecek şekilde; belediye ve kent yönetimi içerisinde sürekli dirsek temasıyla çalışmalarını sürdüren danışma niteliğine sahip bir meclis olarak kurulmuştur (Yücel, 2018:Kişisel Görüşme).

2004 yılında dönemin belediye başkanının Almanya'ya gerçekleştirdiği bir ziyaret esnasında varlığına şahit olunan Yabancılar Meclisi örneğinin Alanya'da da uygulanabileceği fikri ortaya çıkmıştır. O dönemde kentte yaşayan yabancıların özellikle belediyede sahip oldukları su abaonelikleri üzerinden (Öktem vd., 2016:80) tespit edilmesi ve adreslerine İngilizce, Almanya ve Türkçe olarak üç farklı dilde davet metinlerinin gönderilmesi ve yabancıların da konudan haberdar edilmesiyle meclisin kuruluş faaliyetleri başlamıştır. İlk aşamada yerleşik yabancılar tarafından beklenenin üzerinde ilgi gösterilmesi, meclisin sağlam temellerle şekillendirerek süreklilik kazanabileceği ve amaçlarını etkin bir şekilde yerine getirebileceği yönünde pozitif bir dayanak oluşturmuştur. Tamamen gönüllülük esasına dayanarak Turizm ve Halkla İlişkiler Müdürlüğü çatısı altında kurulmuş olan Yabancılar Meclisi, günümüzde belediye başkanının doğal üye olarak başkanlığını yürütmesi üzerine Özel Kalem Müdürlüğü çatısı altında yer almaktadır (Bolat, 2018:Kişisel Görüşme).

İlk kurulduğu günden bugüne Yabancılar Meclisi pek çok çeşitli milletten üyeyi bünyesinde barındırmaktadır. 2017 yılında mecliste Almanya, Türkiye, İran, İngiltere, İrlanda, Hollanda, Danimarka, Rusya, Polonya, Norveç, Finlandiya, İsviçre, Azerbaycan, Litvanya ve son olarak Suriye olmak üzere toplam 15 ülkeden 37 üye bulunurken; 2019 güncel yapısı içerisinde Suriye, İsviçre ve Azerbaycan uyruklu üyelerin ayrılması ve Ukrayna, Kamerun, Kanada, Gürcistan ve Kamboçya uyruklu temsilcilerin dahil olmasiyla 16 ülkeden 40 üye bulunmaktadır. Mecliste bireysel üyeliğin yanında yabancı dernek ve sivil toplum temsilcileri de yer almaktadır. Ayrıca Kamboçya Üniversitesi yabanc1 uyruklu bir birey de mecliste üye olarak yer almıştır ${ }^{12}$. Meclis içerisindeki üyeler genel mahiyette kentte bulunan yabanc1 ülke dernek ve sivil toplum örgütlerinin temsilcilerinin katılımına; daha geniş kitlelere daha hızlı ulaşabildikleri gerekçesiyle önem verilmektedir. Mecliste yer alan üye ülkelerden 7-8 tanesi dernek başkanları düzeyinde temsil edilmektedir. Ayrıca kentte bulunan üniversitelerde okuyan yabancı uyruklu öğrencilerin temsilcileri de Yabancılar Meclisi’nde üye olarak yer almaktadır (Bolat, 2018:Kişisel Görüşme).

Yabancılar Meclisi'nin üye profili kentte yaşayan ne kadar değişik ülke vatandaşı varsa hepsinden en az bir üye olması üzerine oluşturulurken, gönüllülük esasına dayalı olarak bu meclise üye olmak isteyen yabanc1 vatandaşlardan Türkçe, İngilizce, Almanca ve Rusça dillerinden en az birini konuşuyor olmaları istenmektedir. Meclise üye olmak isteyen yabancılar, taleplerini ilettikten sonra meclisin aylık toplantılarından birine katılarak orada kendisini tanıtmaktadır. Neden üye olmak istediğine yönelik açıklamaları gerçekleştirdikten sonra kabul görür ise 4 aylık süreçte meclisin olağan 4 toplantısına katılarak meclis üyeleri ve aday üye arasında iletişim gerçekleşmektedir. 4 ayın sonunda süreç her iki taraf içinde olumlu sonuçlanırsa oylama yapılarak adayın

12 Bkz.: http://alanyayabancilarmeclisi.com/P/1062/Meclis-Uyeleri, (Erişim Tarihi: 18.11.2019). 
YILDIRIM, Burak ve AYHAN, Bekir - Küreselleşmenin Kent Yönetimlerinde Meydana Getirdiği Değişim: Yabancılar Meclisi, Alanya Örneği

kabulü sağlanmaktadır. Meclisten üyenin çıkarılması da aynı şekilde gerekleri ortaya konularak oylama usulü ile gerçekleştirilmektedir. Ancak meclis içerisinde yer alan, yabancı uyruklu üniversite öğrencilerinin temsilcileri üyelik ve üyelikten çıkarılma usullerine tabii tutulmamaktadır. Üniversitedeki yabancı öğrencilerin temsilcileri, öğrenciler tarafından veya üniversite yönetiminin yönlendirmesi üzerinden 1 yıllık süre için Yabancilar Meclisi'ne üye olmaktadır (Bolat, 2018: Kişisel Görüşme). Mecliste kararlar oy çoğunluğu üzerinden alınmaktadır (Yücel, 2018: Kişisel Görüşme).

Yabancılar meclisi, gönüllülük esası üzerine şekillenmektedir. Faaliyetlerinde devamlılık çok büyük önem arz etmektedir. Ayrıca gönüllülük üzerine ş̧ekillenen yapısını destekler nitelikte olarak belediye bütçesinden meclise ayrıca bir pay ayrılmamaktadır. Bu noktada yapılacak olan değerlendirmeler, meclisin devamlılığı üzerine önemli dayanaklar oluşturmaktadır. Gönüllülük esasına göre şekillenen meclis, dünya üzerindeki çeşitli örneklere görüldügünün aksine seçim yasalarına ve belirli katı kurallara dayanmadığı için emsallerine nazaran bir temsiliyet krizi yaşanmamaktadır (Bolat, 2018: Kişisel Görüşme).

\subsubsection{Meclisin Kuruluş Amaçları ve Çalışma Usulü}

Yabancılar Meclisi'nin kuruluş amaçları aşağıda yer verildiği gibi sıralanmaktadır ${ }^{13}$;

- Kentte yerleşik olarak yaşayan yabancıların kente uyumunu ilgili yasal düzenlemelere dayanarak sağlamaya yönelik faaliyetlerde bulunmak.

- Kentte yerleşik olarak bulunan yabancıların kent yönetiminde yer almasına ve kent yönetimi ile iletişimin kurmasina yardımci olmak.

- Kentte bulunan yerleşik yabancıların her türlü bürokratik ve sosyal sorunlarına, istek ve temennilerine cevap vermeye çalışmak.

- Kentte düzenlenecek çeşitli aktiviteler aracılığı kentin ulusal ve uluslararası alanlarda tanıtımını yapmak.

Meclis, kuruluş amaçları olarak sıralanan genel çerçevedeki maddeler ve onların alt başlıkları ile çeşitlenen yeni amaçlar doğrultusunda çalışmalarını değerlendirmekte ve geliştirmektedir. Geliştirilen yeni hedefler doğrultusunda çeşitlenen çalışma başlıkları, meclis faaliyetleri üzerinde yeni hareket alanları oluşturarak kente ve kent yönetimine farklı mahiyetlerde güncel bir dinamizm kazandırmaktadır. Alanya'da yaşayan yabancıların çalışma usulleri doğrultusunda kent yönetime dahil olmaları yerli vatandaşların da yönetime katılımını olumlu bir örnek sunarak desteklemektedir. Bu doğrultuda yerel demokrasinin, katılımcılığın ve hizmetlerin vatandaşa en yakın birimler aracılığı ile vatandaş destekli olarak gerçekleşmesinin önemli bir çıktısını oluşturarak yönetim bilimi alanına önemli bir emsal teşkil etmektedir.

Kuruluş amaçları doğrultusunda Yabancılar Meclisi her ay düzenli bir şekilde toplanmaktadır. Toplantı gündemleri, meclise ulaşan sorunlar üzerinden derlenerek önceden belirlenmektedir. Toplantılarda alınan kararlar ve gerçekleştirilecek faaliyetler üzerine düzenlemeler, kayda geçirilerek gereği yerine getirilmektedir. Yabancılar meclisiyle doğrudan iletişime geçilmek istenildiğinde, kendi sitelerinde paylaşmış bulundukları iletişim bilgileri üzerinden gerçekleştirilebilmektedir. Ayrıca meclisin haftanın iki günü saat 13.30 - 15.30 arasında açı bulunan bürosuna gidilerek doğrudan meclis üyeleri ile iletişime geçilebilmektedir (Bolat, 2018: Kişisel Görüşme).

\subsubsection{Meclisin Faaliyetleri}

Alanya Belediyesi Yabanc1lar Meclisi kuruluşundan günümüze çalışma usullerine riayet ederek, kuruluş amaçlarını uygun hareket ederek ve amaçlarını değerlendirip geliştirerek çeşitli faaliyetler gerçekleştirmektedir. $\mathrm{Bu}$ faaliyetler, Yabancı ülke vatandaşlarının yaşamlarını kolaylaştırıcı gerekli bilgilerin olduğu çeşitli kitap ve broşür bastırılarak bilgilendirme sağlanmaktadır ${ }^{14}$. Bu sayede kente yeni yerleşmiş yabancıların ve yerli halkın, meclisin varlığından ve faaliyetlerinden haberdar olmasına katkı sunulmaktadır.

Yerleşik yabancıların sosyal ve bürokratik sorunlara çözüm getirilmeye çalışılmakta ve de sorunların çözümleri için gerekli idari birimlere yönlendirmeler yapılmaktadır. Örneğin emniyet, göç idaresi veya SGK ile ilgili konular üzerine gelen çözüm taleplerini için kurumların yetkilileri ile iletişime geçerek yapılan yönlendirme ve bilgilendirme ile sorunun çözümüne katkıda bulunmaktadır. Burada vatandaş sorunlarının çözülmesi için kurumlar arası iletişim ile sürecin daha hızlı ilerlemesi yönünde bir müdahale söz konusu olmaktadır (Bolat, 2018: Kişisel Görüşme).

13 Bkz. http://alanyayabancilarmeclisi.com/P/11/Hakkimizda, (Erişim Tarihi: 18.11.2019).

14 Bkz. http://alanyayabancilarmeclisi.com/P/36/Faaliyet-Raporu, (Erişim Tarihi: 18.11.2019). 
Yabancı vatandaşların uyumu için ülkemizde gerçekleştirilmiş yasal düzenlemeler hakkında yerleşik yabancılara bilgilendirme yapılmaktadır. Ayrıca ülkeler aras1 yasa farkl11ıklarından kaynaklanan uluslararas1 sorunları, Türkiye'deki üst düzey idari makamlarla görüşme yapılarak çözüm arayışında yer almaktadır. Örneğin 2013 yılında çıkarılan 6458 sayılı Yabancılar ve Uluslararası Koruma Kanunu hakkında bilgi almak maksadıyla ve ülkeler arası yasa farklılıklarından kaynaklanan uluslararası sorunları bakana iletmek üzere 2014 yılında Avrupa Birliği Bakanı ve bakanlıktan bir heyetle görüşme yapılmıştır ${ }^{15}$. Bu noktada Yabancılar Meclisi'nin uluslararası iletişimi yanı sıra ulusal yönetim yapısı içerisinde de üst düzey idari birimler ile yerel yönetim kademeleri arasında bir köprü vazifesi gördüğü yorumu getirilebilmektedir.

Yabancılar Meclisi kuruluş amaçları doğrultusunda gerçekleştirdikleri faaliyetler aracılığı ile bir yandan Alanya'da bulunan yerleşik yabancıların sorunlarına çözüm üretip onların kent yönetimlerine katılımını sağlarken diğer yandan da yaptıkları faaliyetler aracılığı ile kentin ulusal ve uluslararası alanlarda tanınırlı̆̆ına büyük katkıda bulunmaktadır. Yabancılar Meclisi "Alanya İkinci Avrupa” sloganıyla tanınırlı̆̆ üzerine etkin faaliyetler yürütürken aynı hareket noktası üzerinden Türkiye'nin Avrupa Birliğine üyelik sürecinin hızlandığ dönemlerde İngilizce-Türkçe metinler hazırlayarak kendi büyükelçiliklerine ve ulaşabildikleri resmi kurumlara "Biz Avrupa Birliği'ni Hak Ediyoruz" şeklinde imza kampanyaları düzenleyerek sürece katk1 sunma çabası içerisine girmiştir. Ayrıca küresel anlamda iletişim sistemleri üzerine meydana gelen gelişmeler, meclisin internet, gazete $\mathrm{vb} . .$. iletişim ağları üzerinden kentin tanıtımına dolayısıyla turizme ve kent ekonomisine önemli bir pozitif dışsallık sunmaktadır (Bolat, 2018:Kişisel Görüşme).

Meclisin üyeleri aracıllğıyla uluslararası resmi devlet kurumları ve temsilcilikleriyle geliştirdiği iletişim türü, küreselleşmenin etkisiyle ortadan kalkmış bulunan sınırların aşıldığının göstergesi olarak görülmektedir. Yabancılar Meclisi "Küresel için Yerelde Birliktelik" mottosunu destekler nitelikte gerçekleştirilmiş etkin iletişim gücü sayesinde, uluslararası alanda üst düzey devlet kademelerinin aracılığı devre dışı bırakılarak, yerel düzeyde uluslararası diyaloğun gelişmesine ciddi katkılar sunmaktadır.

Yabancılar Meclisi, belediyenin de desteğiyle her yıl Turizm ve Sanat Festivali, Noel Pazarı Etkinliği, Alanya'nın Sanatı Sergileri ve müftülük tarafindan her yıl gerçekleştirilen iftar yemekleriyle birden çok dinin, dilin ve medeniyetin etkileşim içerisine girmesiyle kültürel kaynaşma meydana getirmektedir (Bolat, 2018:Kişisel Görüşme). Gerçekleştirilen faaliyetlerle kentte bulunan çeşitli etnik kökenden gelen halkların bir araya gelmesi, aralarındaki iletişimin güçlenmesine ve kentin bu etnik çeşitlilikten beslenerek şekillenmesine önemli katkılar sunmaktadır. Danışma kurulu niteliğinde olan bu kuruluşun faaliyetlerinin çok geniş alanlarda yankı bulması ve kentteki pek çok çeşitliliği bir arada barındırabilmesi, başta Avrupa Birliği olmak üzere pek çok uluslararası kuruluşa ve dünyadaki pek çok kente örnek teşkil etmektedir.

Yabancılar meclisinin aktif bir şekilde gerçekleştirdikleri faaliyetleriyle kent yönetimine, özellikle de kentte bulunan farklı temsil gruplarına, kent konseyi içerisindeki çeşitli meclis yapılarına, farklı dinamizm kazandırarak bu yapılar içerisinde de yeni bir hareket alanı oluşturmuştur (Yücel, 2018: Kişisel Görüşme). Yabancılar Meclisi'nin ve yabancıların varlığı Alanya Belediyesi tarafından yapılmış bulunan SWOT analizi içerisinde bir değerlendirmeye tabi tutularak, kentin kent yönetiminin güçlü yanlarını oluşturduğu sonucuna ulaşılmıştır (Alanya Belediyesi, 2014:324).

\subsection{Yabancılar Meclisinin Yönetim Anlayışında Meydana Getirdiği Değişim}

Küreselleşmenin dünyada yayılması, yönetim alanında da dolaylı olarak etkilerini göstermeye başlamıştır. Küreselleşme yönetim bilimi üzerindeki etkilerini gösterdiği alanlardan birini de, yönetişim anlayışı üzerinden yansıtmıştır. Yönetişimin katılımcılık, yerel demokrasi, adem-i merkeziyet, subsidiarite, gibi niteliklerle ifade edilmesi genel yönetim alanı ve kent yönetimlerinin de bu perspektifte gelişmesine etki etmektedir. Yabancılar Meclisi'nin kent yönetimi içerisine dahil olması, kentte bulunan yerleşik yabancıların kent yönetimine katılımını arttırmakta ve bir noktaya kadar yerel demokrasiye, adem-i merkeziyetçiliğe, subsidiyarite ilkesine önemli katkıda bulunmaktadır. Yabancılar Meclisi’nin varlığı kent yönetiminin yerleşik yabancılarla iletişiminin güçlenmesine, iletişim kopukluğu ve tarafların birbirini anlayamaması gibi sorunları ortadan kaldırmasına yardımcı olmaktadır.

Yabancılar Meclisi'nde belediye başkanının doğal üye sıfatıyla ve meclis başkanı olarak bulunması, meclis ve belediye başkanı arasında doğrudan iletişimi güçlendirmektedir. Örneğin bir konu hakkında bilgilendirme yapılması gerektiğinde belediye başkanı mecliste yer alan İngiliz, Rus, Alman ve Türk üyelerin temsilcilerini

15 Bkz. http://alanyayabancilarmeclisi.com/P/36/Faaliyet-Raporu, (Erişim Tarihi: 18.11.2019). 
YILDIRIM, Burak ve AYHAN, Bekir - Küreselleşmenin Kent Yönetimlerinde Meydana Getirdiği Değişim: Yabancılar Meclisi, Alanya Örneği

çağırarak bilgi almaktadır. Ayrıca meclis içerisinde planlanan veya gerçekleştirilen faaliyetler meclisin çalışma alanı içerisinde halledilemeyecek bir konuysa ve bu konuda belediye meclisinde görüşme gerçekleştirilmesi gerekiyorsa, belediye başkanının onayı ile konu belediye meclisinde karara bağlanabilmektedir. Bu noktada Yabancılar Meclisi'nin kent yönetimi ve belediye başkanı ile ilişkileri "Güçlü bir iletişim, dikey hareketlilik" şeklinde ifadesini bulmaktadır (Bolat, 2018:Kişisel Görüşme). Güçlü iletişim ve dikey hareketlilik sayesinde yönetim alanı içerisinde kırtasiyecilik ve yavaş bürokrasi gibi yönetimi yavaşlatan engeller aşılmaktadır.

Alanya'da bulunan Yabancilar Meclisi'nin aktif bir şekilde faaliyetlerini yürütmesi, kentte bulunan diğer vatandaş ve aktörlerin de kent yönetimine katılımını arttırmaktadır. Alanya kent konseyinde yer alan çeşitli meclislerle yapılan işbirliği sonucu kadın meclisi, gençlik meclisi, engelsiz kent meclisi, üniversite meclisi, çocuk meclisi faaliyetlerine olumlu yönde katkı sunmaktadır (Bolat, 2018:Kişisel Görüşme).

Yabancılar meclisi üyeleri belediyenin ve kent konseyinin toplantılarına ve faaliyetlerine sürekli davet edilmektedir. Sadece kendilerini ilgilendiren konulara değil kendi sorunları dışındaki sorunlar içinde katkı sunmak adına zaman zaman çeşitli önerilerde bulunmaktadır. Ancak yabancılar meclisi kent konseyi içerisindeki meclisler arasında yer alan bir meclis değildir ve bu yönde bir talepleri de bulunmamaktadır. Yabancılar Meclisi'nin 2004 yılında kurulması ve mevcut yapılarının daha işlevsel ve geliştirilebilir hareket alanlarına sahip olması gerekçesiyle kent konseyi içerisinde yer almak istememektedir. Kent konseyi içerisindeki meclisler aracılığı ile çözüme kavuşturulan sorunlara duyarlılık göstermekle birlikte kendi sorunlarına belediyenin, kendi sivil toplum örgütlerinin yani genel kapsamda Yabacılar Meclisi çatısı altında çözüm bulmaktadır (Bolat, 2018:Kişisel Görüşme).

Yabancılar Meclisi'nin ayrı bir meclis olarak var olması ve kent konseyindeki diğer meclislerle belediye başkanıyla, üniversitelerle, sivil toplum örgütleriyle, resmi kurum ve kuruluşlarla yerli vatandaşlarla genel olarak kent yönetimi ile iletişiminin güçlü olması, alınan kararların ve gerçekleştirilen faaliyetlerin katılımcılığın önem az etmesi, devamlılığın sağlanması adına ortak karar alınarak gerçekleştirilmektedir. Yabancılar Meclisi, Alanya kent yönetimi içerisinde yönetişim varlığı ve işlevselliği üzerine önemli ve olumlu katk1 oluşturmaktadır. Meclisin yönetim anlayışındaki değişim ve gelişimin gerçekleşmesinde, yaygınlaşmasında emsal niteliğinde olduğu görülmektedir.

Yönetsel anlamda katkıyı destekler nitelikte olacak şekilde, kentin tanınırlığını arttırarak kentin dışarıdan yatırımcıları kendine çekmesinde ve kent ekonomisinin canlanmasında büyük etkileri söz konusu olmaktadır. Yabancılar meclisinin kente ve kent yönetimine katkısıyla ulusal ve uluslararası alandaki aktörlere karşı Alanya önemli bir örnek oluşturmaktadır. Alanya Belediyesi’nin 2014 faaliyet raporunda yer verdiği SWOT analizi sonucunda kentin güçlü yanları arasında Yabancılar Meclisi’nin kentte varlığının gösterilmesi şimdiye kadar anlatılanları destekler niteliktedir (Alanya Belediyesi, 2014:324).

\section{SONUÇ}

1980 sonrası süreçte küreselleşmenin doğrudan ve dolaylı etkisiyle meydana gelen zaman-mekan döngüsündeki değişimler, sosyokültürel, ekonomik, siyasal ve yönetsel alanlarda bir takım değişiklikler meydana getirmektedir. Farklı alanlardaki değişiklikler, uluslararası düzeyde meydana gelen düzenlemelere bağlı olarak şekillenmektedir.

Malların ve sermayenin sınırları aşıp hızlı bir şekilde dolaşıma girmesi ve yayılması zaman içerisinde insanların (emeğin) sınırları aşıp dolaşıma girmesini tetikleyen etkenlerden olmuştur. İnsanların uluslararası düzeyde hareket alanlarını geliştirmeleri ve genişletmeleri dolaylı olarak ulusal sınırların belirsizleşmesine sebebiyet vermektedir. Ulusal sınırların belirsizleşmesi ve ulus devletlerin uluslararası arenada hakimiyet mücadelesi içerisine girmeye başlaması sosyokültürel, ekonomik alanların yanı sıra siyasal ve yönetsel alanlardaki katı, hiyerarşik yapılar üzerinde küreselleşmenin getirdiği dolaylı etkileri göstermektedir.

Küreselleşmeyle birlikte devletler uluslararası ve kendi ulusal yapısı içerisinde yerel düzeydeki yönetim kademelerinde yetki ve görev paylaşımına giderek, uluslararası hareketliliklerle meydana gelen ve dolaşım hızını arttırmaya yönelik yeni alanlara katkı sunmaktadır. Özelikle yerel düzeydeki yönetim kademeleri, uluslararası alanlarda ulusal sınırların dışına merkezi yönetimlerden bağımsız olarak eklemlenebilmektedir. Bu çerçevede insan hareketlerinin hızlanmasıyla uluslararası göç hareketlerindeki artış, insanın ayrıldığı ve vardığı yerler üzerindeki en hızlı ve etkin yönlerini yerel yönetim kademelerinde gösterdiğgi görülmektedir. 
Sınırların ortadan kalkmasıyla birlikte sorunlar veya düzenlemeler ile ilgili belirli yasal dayanakların oluşturulması düşüncesi belirmeye başlamış ve bu yönde başta Avrupa Birliği olmak üzere pek çok uluslararası kuruluş aracılığıyla çeşitli düzenlemeler gerçekleştirilmektedir.

Bir yerden başka bir yere giden insan hareketliliği ile şekillenen yeni kentler, çok dilli, dinli, etnikli, yani çok medeniyetli bir yapıya bürünmektedir. Yeniden şekillenen ve tek milletten insanın barındığ 1 kent yapılarından sıyrılan yeni kentlerde de kent yönetimlerinin oluşan etkiler üzerinden yeniden şekillenmek ihtiyacı meydana gelmektedir.

Uluslararası alanda çeşitli yasal dayanaklarla oluşturulan ve Türkiye'de Almanya'daki emsalleri incelenerek şekillenen ve gönüllülük esasına dayanan "Yabancılar Meclisi" uygulamaları, kent yönetimlerindeki değişimlere ve gelişimlere önemli bir örnek sunmaktadır. Alanya Belediyesi Yabancılar Meclisi, danışma kurulu niteliğine dayalı olarak oluşturulan meclis yapısıyla kentte bulunan milletlerin temsiliyetine imkan sunmaktadır. Bu şekilde katılımcılık üzerinde özellikle de yerleşik yabancı olarak ifade edilen kesimin yönetsel alanda alınan kararlara katkı sunması önemli bir çıktı oluşturmaktadır. Ayrıca idari birimler arasında dirsek teması içerisinde aracı kurum niteliğinde görev yaparak kent yönetiminin işleyişini hızlandırmaktadır. Sadece yerel düzeyde değil Türkiye'deki üst düzey idari kurumlarla, organlarla iletişime geçerek yabancıların kendi ülkeleri ve Türkiye arasındaki yasal düzenlemelerin farklılığından kaynaklanan uyuşmazlıkların çözümüne katkıda bulunulmaktadır. Ulusal düzeydeki idari kuruluşlarla ortak projeler yürütülerek ülkenin ve kentin gelişmesine katkıda bulunulmaktadir.

Meclisin mevcut yapısı incelendiğinde uluslararası düzeyde çok sesliliğe dayalı bir yapıda bulunmaktadır. Alanya Belediyesi Yabancılar Meclisi, uluslararası düzenlemeler konusunda takipçiliğini korurken asıl olarak temellerini gönüllülük esasına dayandıran ve uyum yasaları ile desteklenen bir yapıya bürünmüştür. Ayrıca gönüllülük esası üzerinden şekillenen faaliyetleriyle ve aktif katılım sergileyerek kent meclislerinde ve kentte bulunan diğer yönetim kademelerinde alınan kararlara yerli vatandaşların katılımını tetikleyici yönde pozitif dışsallık oluşturmaktadır.

Meclis içerisinde yer alan çeşitli milletten temsilcilerin bir kısmı sivil toplum örgütü, dernek, vakıf düzeyinde temsilcilerden oluşması ayrıca Alanya'da bulunan iki üniversiteden de yabancı öğrencilerin temsilcilerinin yer alabilmesi meclis kararına çok sesli bir katılımın olduğunun örneğini sunmaktadır. Ayrıca yüksek temsil düzeyinden insanların meclis üyeleri içerisinde varlığ daha etkin ve hızlı bir şekilde yayılım oluşturmasına sebebiyet vermektedir. Dolayısıyla kent yönetimlerine katılımın hizmete en yakın birimler aracılığıyla ve etkin bir şekilde gerçekleştiğini ve bu yönde gelişim gösterdiğini ispatlamaktadır.

Yabancılar Meclisinin kent yönetiminde etkinliğinin artması ve gelişmesine paralel olarak Alanya'nın uluslararası tanınırlığı ve Türkiye'nin uluslararası arenalarda varlığı üzerine geliştirilen yeni alanlarda ve yerel düzeyle, ulusal ve uluslararası alan arasında yeni iletişim kanalları geliştirilmektedir. Geliştirilen yeni iletişim kanallarının etkin olmasında ve hızlı bir şekilde yayılım göstermesinde küreselleşmenin de etkilerinin yansıdığı alanları destekleyen ve teknolojik ilerlemenin başı çektiği yeni iletişim dizaynları önemli yer tutmaktadır. Oluşturulan iletişim dizaynıyla yönetim alanındaki katı iletişim dili ve diplomasi alanlarının oluşturduğu yorucu ve masraflı kırtasiyecilik de aşılmaktadır. Yabancılar Meclisi "Küresel için yerelde birliktelik" mottosunu destekler nitelikte gerçekleştirilmiş etkin iletişim gücü sayesinde uluslararası alanda üst düzey devlet kademelerinin aracıllğı devre dışı bırakılarak, yerel düzeyde uluslararası diyalogun gelişmesine ciddi katkılar sunmaktadır. Yerel düzeyde ve uluslararası alan arasında Yabancılar Meclisi aracılığıyla geliştirilen iletişim türü, ulus devletlerin de bu alandaki yükünü hafifletmekte ve zaman içerisinde ulus devletlerde takipçi bir merkezi yönetim kademesi oluşabileceğinin göstergelerini sunmaktadır.

Yabacılar Meclisi, küreselleşmenin de dolaylı etkilerinin yansımasıyla şekillenen, değişen kent yönetiminde, "yönetişim" algısının şekillenmesinde ve genel olarak yönetim bilimi alanına ciddi katkı ve pratikler sunmaktadır. Yabancılar Meclisi, Alanya kent yönetimi içerisinde yönetişimin varlığı ve işlevselliği üzerine önemli ve olumlu katkı oluşturmaktadır.

Alanya Beledisi Yabancılar Meclisi, kentte yapılan araştırmalarının sonuçlarına bağlı olarak kentin güçlü yanlarını oluşturmaktadır. Bu perspektifte kentte ve kent yönetiminde değişimlere neden olarak Alanya'nın Türkiye'de ve dünyada ne kadar ayrıcalıklı bir kent olduğu gösterilmiştir. Ayrıca yönetim anlayışındaki değişim ve gelişimin gerçekleşmesinde, yaygınlaşmasında emsal niteliğinde olduğu görülmektedir. 


\section{KAYNAKÇA}

AKDİş ASLANOĞLU, Rana (2000), Kent Kimlik ve Küreselleşme, Ezgi Yayınları, Bursa, 2. Bask1.

ALANYA BELEDIYYSSI (2015), Alanya Belediyesi 2014 Yılı Faaliyet Raporu, Alanya Belediye Başkanlığı Yayın1, http://alanya.bel.tr/Documents/Faaliyet/2014/\#p=324 (Erişim Tarihi: 04.12.2017).

ALANYA KAYMAKAMLIĞI (2019), “Turizm, Alanya'ya Gelen Ziyaretçi Sayısı”, E-Haber, Alanya Kaymakamlığı Kurumsal Web Sayfası, http://www.alanya.gov.tr/alanyada-turizm1 (Erişim Tarihi: 18.11.2019).

ALANYA KENT KONSEYİ (2019), "Rakamlarla Alanya”, E-Haber, Alanya Kent Konseyi Kurumsal Web Sayfas1, http://alanyakentkonseyi.org.tr/S/54/Rakamlarla-Alanya (Erişim tarihi:18.11.2019).

ALANYA YABANCILAR MECLİSİ (2019), "Hakkımızda", E-Bilgi, Alanya Yabancilar Meclisi Kurumsal Web Sayfas1, http://alanyayabancilarmeclisi.com/P/11/Hakkimizda (Erişim Tarihi: 18.11.2019).

ALANYA YABANCILAR MECLİSI (2019), "Yabancılar Meclisi Meclis Üyeleri”, E-Bilgi, Alanya Yabanc1lar Meclisi Kurumsal Web Sayfas1, http://alanyayabancilarmeclisi.com/P/1062/Meclis-Uyeleri (Erişim Tarihi: 18.11.2019).

ALANYA YABANCILAR MECLİSİ (2019), “Alanya Yabancilar Meclisi Faaliyet Raporu”, E-Rapor, http://alanyayabancilarmeclisi.com/P/36/Faaliyet-Raporu (Erişim Tarihi: 18.11.2019).

BAŞ, Cemal (2017), Avrupa Kentsel Şartı, Türk Belediyeler Birliği Yayınları, Ankara, Online Kitap: http://www.tbb.gov.tr/online/kitaplar/avrupa_kentsel_sarti_2017/html5forpc.html (Erişim Tarihi: 27.11.2017).

BEKTAŞ, Cengiz (2010), Kent-Kültür-Demokrasi, Arkeoloji ve Sanat Yayınları, İstanbul.

BOLAT, Nimet (2018), Kişisel Görüşme, Alanya Belediyesi Yabancılar Meclisi Görevlisi, Alanya.

DAOUDOV, Murat (2015), “Türkiye'de Yabancıların Uyumunda Yerel Yönetimlerin Rolü”, Uluslararası Göç ve Mülteci Uyumu Sorununda Kamu Yönetiminin Rolü (Ed. Yakup Bulut), Umuttepe Yayınları, Kocaeli, ss.39-64.

DELIHASANOĞLU, Pınar (2013), “Küreselleşmenin Yerele ve Yerel Yönetimlere Etkileri: Kent Konseyleri Örneği”, Yüksek lisans Tezi, Düzce Üniversitesi Sosyal Bilimler Enstitüsü, Düzce.

ERAT, Veysel (2013), "Yerleşik Yabancıların Yerel Düzeyde Kamusal Hayata Katılımlarında Bir Araç Olarak: Bilgi Edinme ve Dernek Hakkı”, Trakya Üniversitesi Sosyal Bilimler Dergisi, S.15(2), ss.277-290.

FRANKFURT BELEDIYESİ (2019), "Belediye Yabancılar Temsilciliği Usul Kuralları Frankfurt am Main (KAV)", https://www.frankfurt.de/sixcms/detail.php?id=2896\&_ffmpar[_id_inhalt] =176449 (Erişim Tarihi: 18.11.2019).

FRANKFURT BELEDIYESİ (2019), "Hessen Belediye Kanunu (HGO)", E-Mevzuat, https://www.frankfurt.de/sixcms/detail.php?id=2896\&_ffmpar[_id_inhalt]=176453 (Erişim Tarihi: 18.11.2019).

FRANKFURT BELEDIYESİ (2019), “KAV nedir?”, E-Doküman, https://www.frankfurt.de/sixcms/detail.php?id=2896\&_ffmpar[_id_inhalt]=176450 (Erişim Tarihi: 18.11.2019).

GELEKÇİ, Cahit (2011), "Küreselleşme-Yerelleşme Illişkisi", Sosyoloji Konferansları Dergisi, S.31, ss.263277.

GÜLER, Birgül Ayman (2013), Yerel Yönetimler Liberal Açıklamalara Eleştirel Yaklaşım, İmge Kitapevi, Ankara, 4. Bask1.

GÜNEŞ, Muharrem (2004), Küreselleşme Kıskacında Kent ve Politika, Detay Yayınları, Ankara.

HEYWOOD, Andrew (2014), Siyaset (Çev. Bican Şahin), Adres Yayınları, Ankara, 14. Baskı.

KELEŞ, Ruşen (2013), Kentleşme Politikası, İmge Kitapevi, Ankara, 13. Baskı.

KELEŞ, Ruşen ve MENGİ, Ayşegül (2013), Avrupa Birliğinin Bölge Politikaları, Cem Yayınları, İstanbul. 
MAHALLİ İDARELER GENEL MÜDÜRLÜĞÜ (2017), "Yabancıların Yerel Düzeyde Kamusal Yaşama Katılım Sözleşmesi”, E-Mevzuat, http://www.migm.gov.tr/avrupa-konseyi (Erişim Tarihi: 27.11.2017).

MENGİ, Ayşegül (2007), “Avrupa Birliğine Uyum Sürecinde Yerel Yönetimlerle Illgili Düzenlemeler”, Yerellik ve Politika: Küreselleşme Sürecinde Yerel Demokrasi (Ed. Ayşegül Mengi), İmge Kitapevi, Ankara.

OKTAY, Tarkan (2016), "Metropol Kent Yönetimi Yaklaşımları ve Uygulama Modelleri”, Strategic Public Management Journal, S.2(4), ss.49-71.

ÖKMEN, Mustafa ve PARLAK, Bekir (2008), "Modernleşmeden Küreselleşmeye Türk Kent Yönetimleri: Teme Nitelikler, Sorunlar ve Projeksiyonlar", Karamanoğlu Mehmetbey Üniversitesi İktisadi ve İdari Bilimler Fakültesi Dergisi, S.15, ss.199-247.

ÖKTEM, M. Kemal, GÖÇOĞLU, Volkan ve TUNÇ, Şebnem (2016), “Kardeş Şehir Uygulamalarının Yerel Politika Transferine Etkisi: Alanya-Gladbeck Araştırması", Çağdaş Yerel Yönetimler Dergisi, S.25(4), ss.49-86.

ÖZER, Mehmet Akif ve AKÇAKAYA, Murat (2014), Yerel Yönetimler Teorik Boyut, Gazi Kitapevi, Ankara.

ÖZKAYA, Yakup (2017), "Yabancıların Yerel Düzeyde Kamusal Yaşama Katılımına Dair Sözleşme”, EDoküman, http://kisi.deu.edu.tr/yakup.ozkaya/ (Erişim Tarihi: 18.11.2019).

ÖZKUL, Osman (2013), Kültür ve Küreselleşme, Açılım Kitap Yayınları, İstanbul, 2. Bask1.

ŞAHİN, Yusuf (2015), Kentleşme Politikası, Ekin Yayınları, Bursa, 5. Baskı.

ŞENGÜL, Tarık (2001), Kentsel Çelişki ve Siyaset, Wald Yayınları, İstanbul.

TEKELİ, İlhan (2011), Kent, Kentli Hakları, Kentleşme ve Kentsel Dönüşüm Yazıları, Tarih Vakfı Yurt Yayınları, İstanbul.

TOPRAK, Zerrin (2009), "Emekli Yerleşiklerin Yerelde Kamusal Hayata Katıllım İstekliliği ve Yerel Halkla İlişkileri (Antalya İçin Bir Yaklaşım)”, Yönetim Bilimleri Dergisi, S.7(2), ss.99-137.

ULUSLARARASI STRATEJIKK ARAŞTIRMALAR KURUMU (2008), "Yerleşik Yabancıların Türk Toplumuna Entegrasyonu”, USAK Raporları, Ankara.

YAHYAGIL, Mehmet Y. (2011), "Kentlerin Kültürün Gelişmesindeki Etkileri”, Sosyoloji Konferansları Dergisi, S.25, ss.105-120.

YONTAR, İbrahim Güray (2011), Avrupa Konseyi Kararlarında Yerleşik Yabancıların Yerel Düzeyde Seçme ve Seçilme Hakları, Seçkin Yayınları, Ankara.

YÜCEL, Adem Murat (2018), Kişisel Görüşme, Alanya Belediye Başkanı ve Alanya Belediyesi Yabancılar Meclisi Başkanı, Alanya.

Türkiye Cumhuriyeti Anayasası (09.11.1982 tarih ve 17863 (Mükerrer) sayılı Resmi Gazete).

4517 sayılı Avrupa Yerel Topluluklar veya Yönetimler Arasında Sınırötesi İşbirliği Çerçeve Sözleşmesinin Onaylanmasına Dair Kanun (06.02.2000 tarih ve 23956 sayılı Resmi Gazete),

6458 sayılı Yabancılar ve Uluslararası Koruma Kanunu (11.04.2013 tarih ve 28615 (Mükerrer) sayılı Resmi Gazete). 


\section{EK 1:}

\section{"Küreselleşmenin Kent Yönetimlerinde Meydana Getirdiği Değişim: Yabancılar Meclisi, Alanya Örneği”

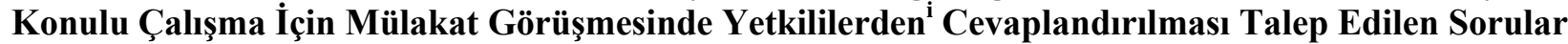

1. Yabancılar Meclisi nasıl kurulmuştur? Kuruluş amaçları nedir? Meclisin kurulma kurulması teklifi yerleşik yabancılardan mı yoksa kent yönetiminden mi gelmiştir?

2. Yabacılar meclisine üyelik ve meclis faaliyetlerine katılım nasıl gerçekleşmektedir?

3. Kentteki yerli vatandaşlar meclisten ve faaliyetlerinden haberdar mıdır? Yerli vatandaşlar tarafından meclise karşı nasıl bir tepki ortaya koyulmaktadır?

4. Kente yeni yerleşmiş yabancı vatandaşların takibi nasıl sağlanmaktadır? Yeni yerleşmiş yabancılar, yabanc1lar meclisinden nasil haberdar olmaktadir?

5. Yabancilar Meclisine üyelik hangi durumlarda sona ermektedir?

6. Yabancılar Meclisinin çalışma usulleri nelerdir?

7. Yabancilar Meclisinin faaliyetleri genel olarak nelerdir?

8. Yabanc1lar Meclisi belediye bünyesindeki hangi birim altına faaliyetlerini yürütüp yönetime dahil olmaktadır?

9. Yabancılar Meclisinin belediyeden talepleri nelerdir? Meclis olmak istediği konumda mı yer almaktadır, ya da geliştirilebilir bir yapı mı öngörülüyor?

10. Yurt dışındaki yabancılar meclisi örneklerindeki gibi temsiliyet krizleri yaşanıyor mu? Örneğin; Almanya'daki temsiliyet krizleri (Frankfurt Yabancılar Meclisi)...

11. Yerleşik yabancıların yasalardan kaynaklanan uyuşmazlık problemlerinin çözümünde yabancılar meclisinin rolü var mıdır, varsa Yabancılar Meclisi yasal uyuşmazlıklarının çözümüne nasıl rol oynamaktadır?

12. Yabancılar Meclisinin uluslararası aktörlerle iletişim konusundaki etkinliği nasıl sağlanmaktadır, kentin ulusal ve uluslararası tanınırlığına nasıl katkı sunmaktadır?

13. Yabancılar Meclisinin kent yönetimine katkısı ve mecliste alınan kararların yaptırım düzeyi nedir?

14. Yabancilar Meclisinin aktif faaliyetlerinin kentte bulunan diğer meclisler (ket konseyi içerisindeki meclis yapıları vs...) üzerinde bir etkisi var mıdır? Varsa bu etkiler nasıl meydana gelmektedir?

15. Yabancılar Meclisinin ayrı bir meclis olarak var olması, diğer meclisler içerisindeki etkinliklerini nasıl etkilemektedir?

16. Yabancılar Meclisinin diğer meclislerle (Belediye meclisi vs...) etkileşimi hangi seviyede ve nasıl gerçekleşmektedir?

17. Yabancılar, meclis aracılığı ile kendilerini ilgilendiren kararlar dışındaki kararlara da katılım sergileyebiliyorlar mi?

18. Yabancılar Meclisinin kente ve kent ekonomisine sunduğu katkı nelerden oluşmaktadır?

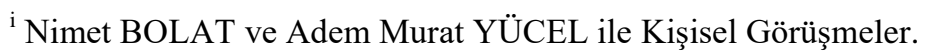

